\title{
Conhecimento e sociedade: diálogos impertinentes
}

ALEXANDRE SILVA VIRGINIO*

\section{VERDADE}

A Porta da Verdade estava aberta, Mas só deixava passar

Meia pessoa de cada vez.

Assim não era possível atingir toda a Verdade, Porque cada metade trazia o perfil da meia verdade E sua segunda metade Voltava igualmente com meio perfil E os meios perfis não coincidiam.

Arrebentaram a porta. Derrubaram a porta. Chegaram ao lugar luminoso Onde a Verdade esplendia seus fogos. Era dividida em metades Diferentes uma da outra.

Chegou-se a discutir qual a metade mais bela, Nenhuma das duas partes era totalmente bela. E carecia optar. Cada um optou conforme Seu capricho, sua ilusão, sua miopia.

Carlos Drummond de Andrade ${ }^{1}$

* Doutorando - PPG-Sociologia/U FRGS/Brasil e Professor da Escola Técnica/U FRGS. Brasil.

1 AND RADE, Carlos Drumonnd de. Verdade. In: ANDRADE, Carlos Drumonnd de. Corpo. 10ª ed. Rio de Janeiro: Record, 1987, pp. 41-42. 


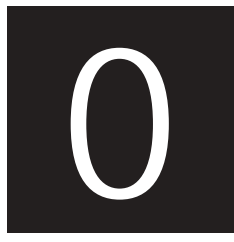

mundo em que vivemos reflete e torna inconfundíveis as marcas de um período de transição. São indeléveis os eixos de mudanças e tranfformações de toda ordem - social, econômica, política, ambiental, cultural e individual que tem caracterizado as sociedades contemporâneas ao longo do século XX e neste início de terceiro milênio. 0 sistema capitalista mundial mostrou-se incapaz de nos proteger da infelicidade e do sofrimento, produtos de nossa implausível capacidade em aceitar . . . a força superior da natureza, a disposição decadente de nossos corpose a inadequação dos nossos métodos de ordenar as relações humanas na família, na comunidade e no Estado (Freud apud Wallerstein, 2002, p. 185). 0 modus vivendi atual tem levado ao extremo o alargamento da distância entre os que têm e os que nada possuem, o lucro máximo coordena as ações econômicas em especial as de caráter financeiro e especulativo -, os governos cada vez mais se submetem aos interesses das grandes corporações transnacionais ou aos imperativos da força militar, a degradação e devastação do meio ambiente nunca foi tão veloz e violenta, a vida cultural tão mais plastificada, massificada e/ou pasteurizada enquanto nós, pessoalmente, jamais estivemos tão coletivamente sozinhos, seqüestrados à vida pública e confinados na ilusão do efêmero, próprio do consumismo irrefreado - tanto para os que podem como para os que desejam e não podem - ou da inconcretude presente nas relações entre o real e o virtual que nos consome à frente da televisão, do computador ou dos jogos eletrônicos.

Este cenário é o quadro resultante do processo de desenvolvimento da sociedade capitalista mundial que, durante muito tempo, foi interpretada, quando não alimentada e legitimada, pelo caráter instrumental da ciência moderna. A vivacidade de seu progresso tem sua raiz no desenvolvimento do capitalismo que a fez sua força motriz na conquista, no domínio e na exploração da natureza. Seu fundamento político, por sua vez, funda- 
menta-se na idéia de que essa exploração era uma vocação, 'natural' e inevitável, do homem (Fourez, 1995; Wallerstein, 2002). Nesta perspectiva, mesmo reconhecendo o valor, a profundidade e a contribuição do racionalismo iluminista, ${ }^{2}$ não podemosaceitar que toda a multidimensionalidade e a complexidade da realidade obedeçam às fronteiras estipuladas pelo racionalismo cartesiano. Como imaginar e aceitar que a ciência possa se ocupar de todas as manifestações possíveis, em manipulações de laboratório (Kuhn, 2003). Este método de descrição da realidade engessou a vida em uma lógica formal, de certa maneira, mecânica e pragmática. Este racionalismo, além de não ser o único racionalismo possível, acabou por cimentar no homem a idéia de progressão dependente de um crescente domínio, senão controle, sobre a natureza (retornaremos a esta questão no decorrer de nossa análise).

Esta perspectiva de relação entre o saber e o mundo desembocou na essência da ciência moderna, ou seja, na certeza da certeza e na promessa do alcance, por parte de todo, dos benefícios materiais e das liberdades individuais e coletivas. Ademais, a ciência moderna carrega consigo alguns predicados que conferem uma linha discernível e identificável. Dentre eles, merece destaque a afirmação de que tudo que existe no universo está sujeito e regido por leis naturais universais, que podem ser expostas a partir de enunciados simples e cuja descoberta e aperfeiçoamento decorrem da investigação empírica levada a cabo por especialistas, isto é, legitimada como saber válido a partir do pronunciamento de cientistas. Afirma ainda que a realidade é resultado de processos lineares que tendem sempre em direção ao equilíbrio no qual a natureza encarna o papel de objeto passivo, manipulável e controlável, portanto de comunicado e não de comunicante (Wallerstein, 2002).

Este racionalismo, que tem seu fundamento básico na existência de leis universais e na M atemática (Santos, 1987; Nicolescu, 1999), não con-

${ }^{2}$ Sobretudo no que diz respeito às ciências sociais. 
templa, apesar de ainda hegemônico, tudo o que há de contingente, subjetivo e circunstancial em nossa existência. Tentar reproduzir a riqueza da vida humana - e cotidiana - dentro de um caminho moldado pelo uso formal das palavras e restrito ao universo da denotação é não reconhecer que somos portadores de outras dimensões, de subjetividades. Q ue até mesmo o uso das palavras não é capaz de espelhar, na totalidade, o significado da realidade. ${ }^{3}$ Ao optarmos, com exclusividade, pela linguagem lógica e analítica tornamo-nosmenos humanos. Assim procedendo, desconsideramosa linguagem cotidiana. E, assim fazendo, deixamos escapar toda a substantividade de nossa vivência cotidiana, todas as singularidades de nosso universo cultural. Ao pensar o homem, não se pode desconsiderar que o mundo em que vivemos, em extensão e profundidade, demanda ser apreendido, ainda que apresente um universo para além de qualquer ambivalência e ainda distante da linha do infinito, a um só tempo, a partir do universal e do particular, da razão e da sensibilidade, da consciência e da existência, da forma e do conteúdo, da teoria e da prática, da aparência e da essência, enfim, da objetividade e da subjetividade.

Deste modo, o esquema cartesiano cuja origem remonta ao século XVIII, está, mais uma vez sendo desafiado. Em conseqüência, o racionalismo lógico - duro - teve sua maior crise na primeira metade do século XX. Ao se constatar não ser possível uma razão única e absoluta, o homem, órfão da pedra angular de seu pensamento, caminhou em direção às fronteiras da irracionalidade, ao perigo de substituir a razão absoluta por razão alguma. Foi o momento, segundo Mannheim, de queda no relativismo. Conforme este autor,

\footnotetext{
3 Por demais, parece-nos inequívoco o entendimento de que a realidade não é nem sequer o que interpretamos dela. N ossas interpretações não passam de ficções possíveis daquela. Portanto, qualquer estudo ou análise da realidade não passa de conjecturas. Com efeito, a realidade social, somente pode ser apreciada em primeira grandeza pelos próprios atores que a constroem e que são por ela construídos. Às ciências sociais cabe edificar conceitos e/ou categorias que possam, além de organizar, ordenar e explicar os acontecimentos, elucidar as estruturas conceituais que informam os sujeitos da ação e, assim fazendo, acrescentar à realidade a compreensão sociológica (Geertz, 1989).
} 
A emergência do problema da multiplicidade de estilos de pensamento surgida no decorrer do desenvolvimento científico e a perceptibilidade de motivações do inconsciente coletivo, anteriormente veladas, é apenas um dos aspectos da preponderância da inquietação intelectual que caracteriza nossa época. (1972, p. 60),

Com efeito, nosso desafio enquanto sujeito/objeto desta e nesta realidade passa por uma perspectiva ambivalente e interdependente. Por um lado, temos que encontrar nosso espaço e nosso tempo nesta realidade e definir nova forma de relação para com ela - se de conformidade ou de construção de caminhos alternativos. De outra parte, premissa de nosso transitar existencial, temos que compreender, senão conhecer, as formas de pensar e/ou de produzir conhecimento que tem, mais ou menos dramaticamente, (con)tornado essa mesma realidade.

N estes termos, o que estaremos apresentando a seguir é um esforço, reconhecidamente modesto, no sentido de procurar conhecer e compreender as conexões entre pensamento e existência. Entrementes, não se trata de recuperar essa relação desde os primórdios do capitalismo. Da mesma forma, não temos a pretensão de tratar de todas as perspectivas inerentes ou próximas ao tema. Em contrapartida, estaremos tramando uma aproximação com alguns autores que, nos seus termos, procuraram significar ou descortinar os vínculos entre conhecimento e interesse, entre produção científica e mercado, entre ciência e sociedade.

Em princípio, ainda que menos pela sua singularidade e mais pela sua substantividade, partiremos das contribuições de Pierre Bourdieu. ${ }^{4}$ Esta é uma opção de caráter reconhecidamente discricionário, portanto de nos-

4 À sua maneira, o aporte colocado por Bourdieu à análise das relações entre ciência e sociedade insere-se no contexto da transição paradigmática entre a ciência moderna e a pós-moderna, cuja gênese pode ser buscada no conceito de relatividade da simultaneidade apresentado por Einstein (Santos, 2000). 
sa inteira responsabilidade. 0 utros poderiam supor partir das contribuições de Kuhn ou de M erton. ${ }^{5}$ Todavia, assumimos aqui o entendimento de que a análise de Bourdieu, numa perspectiva M ertoniana e apesar da ascendência do homo economicus em sua teoria, significou um aprofundamento crítico em relação às ambivalências e dicotomias que envolvem ciência e sociedade, conhecimento e ganho pessoal, ou conhecimento científico e vida social. Ademais, ele deve ser apreendido como um (pre)texto para um conjunto de questões que permeiam o diálogo e/ou debate entre os diferentes saberes produzidos e produtores da realidade cognoscível. Desta forma e correlatamente, após expor as formulações de Bourdieu sobre 0 campo científico, e em meio às críticas desencadeadas por esse autor, estaremos apresentando o dilema do desafio da produção do conhecimento em meio a uma sociedade que, cada vez mais, é cenário e elenco de uma atmosfera infinita e irrefletida de complexidade.

5 As contribuições de M erton e de Kuhn para o avanço do debate envolvendo a sociologia do reconhecimento e a sociologia da educação são, no mínimo, consideráveis. Como aspectos centrais do trabalho do primeiro, lembramoso destaque e as preocupações conferidas por este à explicação do grau de influência dos fatores socioculturaise históricos no desenvolvimento da ciência - inclusive daqueles que impediram tal desenvolvimento - reconhecendo a influência de uma base existencial na determinação do conhecimento, bem como outras formas - hierarquicamente inferiores, segundo ele - de conhecimento. Nestes termos, a produção científica, para Merton, é interdependente de outras esferas, como por exemplo, a econômica, a moral e a religiosa. Essa relação entre ciência e fundamentos sociais não deve supor, segundo M erton, uma submissão do comportamento doscientistas aos imperativos instrumentais, discordando de Bourdieu ao destacar que a socialização daqueles está sujeita a diferentes estilos e práticas sociais (Lima, 1994). Kuhn, de outra parte, não é relutante em dar uma solução ao dilema do relativismo científico com o conceito de paradigma e de comunidade científica. Para ele, o progresso da ciência não obedece a uma evolução linear ou cumulativa. Aliás, o que se expande e se acumula, paradoxalmente ao desenvolvimento da ciência, é o risco da degradação ambiental irreversível (Wallerstein, 2002). U ma mesma realidade, destaca Kuhn, entrementes a superação de um paradigma por outro, pode ser apreendida de forma tão diferente, porquanto diversa. Em seu juízo, 0 alargamento do alcance da ciência se dá, mesmo que os paradigmas possuam um caráter eminentemente aberto - noção que apresenta uma grande semelhança com o conceito de sistemas autopoiéticos incorporados de Maturana por Luhmann -, acolhendo e incorporando novidades, a partir de revoluções científicas - reconstrução de uma área de estudos a partir de novos princípios, teorias, métodose aplicações que proporcionam que os cientistas vejam o mundo de forma diferente reagindo a ele, também, de forma diferente -, isto é, de respostas não-tradicionais a problemas novos e anômalos, até então tratados insatisfatoriamente pelo paradigma tradicional. Por seu turno, diria Wallerstein (2002), o novo paradigma tem sua atualidade e legitimidade baseadas tanto na pertinência de seus esquemas de compreensão, quanto em sua capacidade de resolver os desafios intelectuais colocados por seus críticos. Em seu conceito de comunidade científica, Kuhn, apesar de reconhecer e apontar a influência do contexto sociocultural, tanto na definição dos problemas a resolver quanto sobre o pensamento e as escolhas dos cientistas, apresenta-a distante dos interesses em disputa na sociedade ou, até mesmo, influência do campo econômico sobre seu trabalho. Neste sentido, portanto distante de Bourdieu, a comunidade científica, para Kuhn, é formada por um grupo de cientistas que tem sua motivação no desejo de ser útil, em fazer o que ninguém antes fez. É formada por grupos de profissionais, submissos a uma rede de compromissos ou adesões conceituais, teóricas, metodológicas e instrumentais adesões que em muito poderiam ser explicadas pelo sentido que Bourdieu conferiu ao conceito de habitus-, e cujas especialidades buscam soluções, de preferência detalhadas, aos problemas relativos aos comportamentos da natureza e que devem se dirigir e se submeter aos julgamentos únicos de seus pares (Kuhn, 2003; Hochman, 1994). 


\section{O campo científico na análise de Pierre Bourdieu}

Em seu trabalho de análise do campo científico, Bourdieu (1983), a partir da preocupação central em desvendar os mecanismos e formas de dominação presentes na sociedade, assinala e sustenta que a construção do saber científico e epistemológico é resultado da estrutura e do funcionamento desse campo. ${ }^{6} \mathrm{~N}$ este sentido, também no campo científico verificase uma luta pela imposição ou monopólio da autoridade cientifica, legitimamente reconhecida pelos agentes em disputa, para conferir os critérios de valor e validade científica à produção científica no que concerne, inclusive, à área de pesquisa, à metodologia e à origem e trajetória do pesquisador. ${ }^{7}$ Para Bourdieu, em síntese

A estrutura do campo científico se define, a cada momento, pelo estado das relações de força (que por sua vez está condicionada pela posição dos agentes em outros campos) ${ }^{8}$ entre os protagonistas em luta, agentes ou instituições, isto é, pela estrutura da distribuição do capital específico, resultado das lutas anteriores, que se encontra objetivado nas instituições e nas disposições e que comanda as estratégias e aschances objetivas dos diferentes agentes ou instituições(1983, p. 133).

\footnotetext{
$6 \mathrm{~N}$ a perspectiva de Bourdieu, campo deve ser entendido como a estrutura de relações objetivas entre posições ocupadas pelos agentes e que possui gênese e estrutura específicas pertinentes à propriedade de determinada especificidade e volume de capital, cujos lucros, decorrentes de sua legitimidade - homologia entre o habituse a estrutura do campo - define a posição de dominação ou subordinação do agente no campo. Assim, estruturas que dão vida ao espaco social, cada campo possui uma lógica e necessidades específicas, porquanto próprias e que os agentes, na luta por acúmulo de energia social, acabam por reforçar ou alterar. Com efeito, temoso campo econômico, o lingüístico, o artístico, o da moda, o religioso, o esportivo, o jornalístico, 0 escolar, o científico. O utrossim, dependendo do campo sobre o qual lançamos nosso olhar, poderemos perceber a distinção e dentro de cada campo, os fatores de distinção - de determinados estilos de vida correspondentes à prevalência de determinados tipos de capital (Bourdieu, 1989, 1996, 1996a, 2000, 2002).

7 Em interpretação análoga, Santos (2000) pondera que o cientista movimenta-se no campo científico a partir dos aceites da comunidade científica e as razõese ponderações de sua comunidade interior, isto é, de sua própria racionalidade moral-prática e estético-expressiva. Nas palavras de Santos: Isto significa que o cientista concreto está sempre dividido entre os argumentos que o convencem a si - os argumentos como "valor de uso" simbólico - e os argumentos que convencem a comunidade científica empírica - os argumentos como "valor de troca" simbólico (SANTOS, 2000, p. 103).
}

80 comentário é nosso. 
Neste sentido, a luta dentro desse campo se dá a partir do interesse que move os agentes no interior do campo científico, isto é, a busca por prestígio, reputação, ${ }^{9}$ reconhecimento, ou mesmo de celebridade. Em realidade, Bourdieu coloca relevo na ilusão de se perceber a produção científica como resultado de uma competência técnica asséptica ou desprovida de sentido político, ${ }^{10}$ já que as mesmas estão presas as determinações sociais impostas às práticas dos agentes. Assim, a busca por prestígio e reconhecimento condiciona a escolha da temática o setor de certa disciplina, em função de suas chances de reconhecimento. Destarte, de acordo com Bourdieu, no campo científico

O que é reconhecido como importante e interessante é o que tem chances de ser reconhecido como importante e interessante pelos outros; portanto, aquilo que tem a possibilidade de fazer aparecer aquele que $o$ produz como importante e interessante aos olhos dos outros (1983, p. 125).

Por decorrência, o jogo ou luta no interior do campo científico transcorre a partir do desenvolvimento de estratégias assumidas pelos diferentes jogadores, no sentido de acumulação de capital científico, capital esse que vai condicionar a posição de cada agente no campo. Em conseqüência, aqueles que dominam o campo científico são aqueles que, além de procurarem distinguir-se de seus predecessores, conseguem impor aos demais a definição de ciência e/ou do que é considerado científico. Em outras palavras, são dominantes no campo porque a delimitação e definição particular

\footnotetext{
9 A reputação de um mestre deve ser considerada também como um elemento que interfere na assumpção de um novo paradigma por parte de um cientista (Kuhn, 2003).

10 Este sentido político representou e desaguou, em grande escala e de forma indubitável, em submissão política e governamental dos cientistas. Tanto seus objetos quanto a qualidade de suas pesquisas estiveram presas menos à relevância e ao caráter benéfico à sociedade e mais ao alcance utilitário que apresentam, em relação a uma lógica instrumental, ainda que a mesma represente e contribua para um retrocesso moral da sociedade. Disto decorre, apesar das condições de liberdade presentes nesta ou naquela cultura, que empresários e políticos tiveram um papel importante, seja em inibir certas inovações como em potencializar outras (Wallerstein, 2002).
} 
que fazem dos problemas, das teorias e métodos são reconhecidos como legítimas, ${ }^{11}$ porquanto hegemônicas, no campo científico. A dominação ${ }^{12}$ no campo é, conforme Bourdieu, o resultado do reconhecimento, conferido pelos agentes em disputa, da validade dos critérios que definem os princípios de hierarquização do que está em jogo e que, em verdade, revelam a força de certos grupos de interesse. ${ }^{13}$

De outra parte, a competência científica, produto da consistência e volume de capital científico - que é também simbólico,$-{ }^{14}$ é resultado de uma acumulação de capital, produto da apropriação de um conjunto de sinais específicos de consagração em função do valor distintivo e da originalidade que o cientista traz aos recursos científicos já acumulados. Tais recursos podem, por sua vez, ser ampliad os a partir do acesso a cargos administrativos, comissões governamentais, pela instituição de origem ou por sua reputação entre seus pares. Estes seriam mecanismos ou estratégias utilizadas pelos agentes em sua busca por diferenciação, distinção ou visibilidade dentro do campo. Conforme Bourdieu

11 Isto é, como imposições de verdade e de autoridade que se impõem sem recorrer à força física ou a atos discricionários. 12 De acordo com Bourdieu $(1989,1992)$, na medida em que há conjugação de diferentes hierarquias, presentes nos diferentes camposque constituem e configuram o espaço social e fazem, ao mesmo tempo, emergir o campo de poder, a dominação passa a ser considerada como o resultado do monopólio, por parte do agente ou grupo de agentes, das formas de violência simbólica cujo fundamento principal recai sobre os bens materiais. U m exemplo de violência simbólica é a que ocorre pela imposição, na escola, do discurso erudito às camadas populares.

13 Estes interesses dizem respeito ao rompimento da idéia de ciência asséptica e neutra, imune à contaminação subjetiva ou normativa, construída a partir da aplicação imparcial de critérios técnicos. Revelam, por seu turno que, no transcorrer da interação social, o conhecimento científico possui uma autonomia relativa estando conjunturalmente, social e contextualmente condicionado. Em meados do século passado, $M$ annheim alertava para a falta de perspectiva totalizante da ciência moderna, ao mesmo tempo que denunciava a concepção positivista da ciência como concernente a uma determinada concepção de mundo e de atender a determinados interesses políticose sociais (M annheim, 1982). Na contemporaneidade, esses interesses têm sido direcionados pela razão instrumental que demarcou e caracterizou o paradigma da ciência moderna - ligada à representação de mundo própria da burguesia --, como de resto se constituiu em fator de produção e de poder ao longo do processo de acumulação capitalista. Em seu estágio - mais avançado - de mundialização do poder do capital, a produção do conhecimento, bem como o desenvolvimento da tecnologia e da ciência estiveram, até agora, hegemonizadas pela lógica de acumulação de capital ou de perseguição do lucro máximo cujo extremo, diria Mannheim (1962), seria o cientista que enxerga com os olhos do mercador. 0 lado reverso - ou seria perverso? (O 'sullivan, 2004) -, ainda que em grande parte imensurável, porém previsível, é a insustentabilidade da vida no e do planeta. (Corrêa, 1996; Baumgarten, 2002; Fourez, 1995; Freitag, 1979; Morel, 1979).

14 Capital cuja essência e função derivam da capacidade de produção da crença das palavras de quem as pronuncia, produzindo o desconhecimento da violência objetiva das relações de força presentes no espaço social. Assim, as lutas no interior do campo são lutas para tornar um uso particular em visão geral e o sentido do mundo em natural e social. Esta visão geral, por sua vez, como necessidade social do campo, pressiona a pulsão particular de modo que esta se torne irreconhecível (Bourdieu, 1989). 
... acumular capital é fazer um 'nome', um nome próprio, um nome conhecido e reconhecido, marca que distingue imediatamente seu portador, arrancando-o como forma visível do fundo indiferenciado, despercebido, obscuro, no qual se perde o homem comum (1983, p. 132).

Neste contexto, a disposição e propensão dos agentes a investir ${ }^{15}$ na lutas internas ao campo científico são tanto mais elevadas quanto maior é a possibilidade de reconhecimento. Nesta medida, as estratégiase impulso a investir dependem da relação entre a importância do capital produzido e as chances concretas de "lucro" no campo científico, ou seja, das reais possibilidades de aumento do prestígio e reconhecimento. Portanto, tanto 0 nível quanto o caráter da produtividade do campo, além da posição de dominante ou de sujeito da dominação por parte do agente - posição na estrutura de sua carreira -, são definidos pela aceitação do que é considerado, ou não, como fator de distinção dentro do campo. Para Bourdieu

A estrutura da distribuição do capital científico está na base das transformações do campo científico e se manifesta por intermédio das estratégias de conservação ou de subversão da estrutura que ela mesma produz. Por um lado, a posição que cada agente singular ocupa num dado momento na estrutura do campo científico é a resultante, objetivada nas instituições e incorporada nas disposições, do conjunto de estratégias anteriores desse agente e de seus concorrentes (elas próprias dependentes da estrutura do campo, pois resultam das propriedades estruturais da posição a partir

15 Esta propensão se apresenta na teoria de Bourdieu, mais precisamente, como a Illusio que significa, na gestão do tempo, disposição para atualizar o ainda inatualizado - então assegurado interesse pelo jogo - cuja seqüência depende da crença em seu futuro, nas oportunidades- lusiones. 0 bom jogador não é aquele que se submete à visão de projeto, onde o porvir se torna incontornável, onde o provável é apreendido pela consciência como verdade de um futuro contingente. Pelo contrário, o bom jogador é aquele que se antecipa ao futuro visto que ... o porvir em relação ao qual ele se determina não é um possível que pode ou não acontecer, mas alguma coisa que já está aí na configuração do jogo e nas posições e posturas presentes dos parceiros e dosadversários. (BO URDIEU, 2001, p. 254-255) 
da qual são engendradas). Por outro lado, as transformações da estrutura do campo são o produto de estratégias de conservação ou de subversão que tem seu princípio de orientação e eficácia nas propriedades da posição que ocupam aqueles que as produzem no interior da estrutura do campo (1983, p. 134).

Ademais, o campo científico se constitui num espaço de luta, cuja desigualdade ante o desafio de contrair e acumular capital científico é definida a partir do maior ou menor volume de capital, compondo uma hierarquia e diferenciações configuradas pela posição do agente em relação à estrutura de distribuição de capital no campo e com certa dependência da posição dos agentes na estrutura de campos exógenos ${ }^{16}$ ao campo científico. D esse modo, os agentes dominantes, cujo habitus ${ }^{17}$ corresponde a uma posição privilegiada na estrutura de distribuição do capital científico, desenvolvem estratégias de conservação da ordem científica, qual seja, do conjunto de instituições que garantem a circulação dos bens científicos, dos produtorese consumidores, de modo a garantir a inculcação e/ou a reificação de práticas incorporadas e responsáveis pelo consenso em torno do qual se travam as lutas no campo.

\footnotetext{
16 Em realidade, isso tende a significar que as ações dos cientistas estariam submetidas à lógica das determinações econômicas e sociais impostas ao campo científico pela estrutura social (Hochman, 1994).

17 Por habitus, assevera Bourdieu, deve-se considerar o conjunto ou . . . sistemas de disposições duráveis, estruturas estruturadas predispostas a funcionar como estruturas estruturantes, isto é, como princípio gerador e estruturador das práticas e das representações que podem ser objetivamente 'reguladas' e 'regulares' sem ser o produto da obediência a regras, objetivamente adaptadas a seu fim sem supor a intenção consciente dos fins e o domínio expresso das operações necessárias para atingi-los e coletivamente orquestradas, sem ser o produto da ação organizadora de um regente. (BO URDIEU, 1983, p. 60-61). Desta forma, a relação entre o habituse o campo é, antes de tudo, uma relação de condicionamento e de retro-alimentação. 0 habitus contribui para construir o campo como mundo significante, dotado de sentido e de valor, no qual vale a pena investir energia. Esse investimento reforça, senão reproduz, as estruturas e/ou categorias que conferem sentido e significado para os agentes no interior do campo. Entrementes, o conceito de habitusé o que permite a articulação entre o individual e o social, 0 agente e a sociedade. Conforme Bourdieu, o habitus impõe a dinâmica da socialização, realizando a incorporação dos habitus de classe - que pode ser próximo ou distante das estruturas que definem a legitimidade do capital adquirido -, produz a filiação de classe dos indivíduos, muito em razão de suas condições objetivas de existência, porém de forma inconsciente, reproduzindo, ao mesmo tempo, a classe enquanto grupo que compartilha o mesmo habitus. Este conceito está na base de produção social apesar de ser, segundo Bourdieu, tanto um mecanismo de conservação como de invenção, de mudança. Esta formulação apresenta, em boa medida, certa congruência com a idéia de "principia média" cunhada por M annheim. Estes seriam, para esse autor, um conjunto de forças universais, presentes em determinado contexto social e histórico, que faria com que cada pessoa percebesse e intuísse o mundo social a partir de um horizonte comum de expectativas construídas na constância da experiência social. Nesta perspectiva, um conjunto de "principia média" articulados resultaria na estrutura, e a alteração destes fatores gerais que condicionam as expectativas resultaria em mudança estrutural (Mannheim, 1962, 1982).
} 
De forma inversa, os dominados, com interesses e meios distintos, assumem as estratégias de sucessão, visando acessar os lucros decorrentes do acesso ao capital científico legitimado no interior do campo ou, inversamente, adotar as estratégias de subversão que visam romper com os princípios e critérios legitimadores do capital científico, substituindo-os por outros, o que pressupõe, por conseguinte, a não participação no ciclo das trocas de reconhecimento.

Não obstante, Bourdieu (1983) sustenta que, quanto maior a homogeneidade no interior do campo, decresce a probabilidade de alteração das posições dos agentes nesse campo. Com a elevação dos recursos científicos disponíveis, tem-se um maior equilíbrio entre os capitais disponíveis dos e entre os agentes. O utrossim, a posição dos agentes diante da estrutura de distribuição de capital científico estará mais suscetível à posição que cada agente possui em relação à estrutura do capital em outros campos. Nesta perspectiva, as estratégias de conservação ou subversão próprias ao campo científico dependem da maior ou menor dependência desse campo à ordem social ou à formação histórica na qual está inserida. Em função disto, toda revolução contra as instituições ou ordem científicas é também revolução contra a ordem estabelecida.

Em sentido convergente, Bourdieu (1983) sublinha o que para ele, dentro do campo científico, cumpre um papel de dominação e de imposição ideológica. No momento em que o domínio do campo científico e, portanto, da imposição legítima e hegemônica de determinadas teorias científicas, acontece pela imposição de um arbitrário social e cultural por parte de certos grupos que transformam interesses científicos privados em interesses gerais da ciência, ${ }^{18}$ temos a imposição e a transposição,

18 Esta subordinação e autonomia condicionada da ciência às esferas econômica e política também é identificada, dentre outros, por Rouanet e Wallerstein. Para o primeiro. . . a ciência deixou de ser autônoma, sendo capturada pelo complexo industrialmilitar. Nesta medida ela se desvinculou de fins éticos, pondo-se a serviço da guerra e da destruição. Pode transformar-se, ao contrário, numa logocracia despótica, na medida em que legitima formas de organização baseadas em imperativos técnicosistêmicos, que devem ser obedecidos sem qualquer discussão por parte dos diretamente interessados (Rouanet, 1993, p. 24). 
comumente consentida, de uma visão particular em geral, de uma necessidade singular em necessidade universal. ${ }^{19}$

O que movimenta o campo e, ao mesmo tempo, paradoxalmente garante sua reprodução, são, segundo Bourdieu (1983), para além da revolução inaugural, pequenas e contínuas revoluções. ${ }^{20}$ Para ele, a acumulação do capital científico necessário à revolução científica diminui a distância entre conservação e subversão, visto que a ruptura contínua reforça o princípio da continuidade, e as estratégias de luta dos agentes obedecem aos padrões impostos à carreira. Assim, a maior ou menor tensão dialética do habitus em relação ao campo científico acaba por revelar o caráter funcional da própria lógica desse campo. Submersos na luta concorrencial por acúmulo de capital, os agentes deixam de reconhecer o que orienta a estrutura de funcionamento do campo científico, isto é, sua doxa. ${ }^{21}$ Esta deve ser apreendida, segundo Bourdieu, como 0

... consenso sobre os objetos de dissensão, os interesses comuns que estão na base dos conflitos de interesses, todo o não-discutido, o não-pensado, tacitamente mantidos fora dos limites da luta. (1983, p. 146).

\footnotetext{
Em sentido convergente, Wallerstein (2002, p. 214) sustenta: A ciência social se tornou conselheira (empregada?) dosformuladores de políticas, do panóptico de Bentham à Verein für Sozialpolitik, do Relatório Beveridge e infinitas comissões governamentais às séries pós-guerra da UNESCO sobre racismo, às pesquisas sucessivas de James Coleman sobre o sistema educacional dos Estados Unidos. Após a II Guerra M undial, a noção de 'países desenvolvidose subdesenvolvidos' constituiu uma rubrica que justificou o envolvimento de cientistas sociais de todas as persuasões políticas na reorganização social e política do mundo não ocidental.

19 Temos aqui uma outra forma - mais elaborada, no nosso entendimento, porque reflexo da dominação subsumida na violência simbólica - de expor, principalmente se considerarmoso campo econômico, o que Marx já assinalava ainda na primeira metade do século XIX, ou seja, que Asidéias da classe dominante são, em cada época, as idéias dominantes; isto é, a classe que é a força material dominante da sociedade é, ao mesmo tempo, sua força espiritual dominante. (M arx, K \& Engels, F., 1993, p. 72).

20 Concepção que acumula dívida com as análises de Kuhn.

21 D oxa são as representações dominantes, isto é, o conjunto das opiniões comuns, crenças estabelecidas, idéias preconcebidas, o que é obvio e não é discutido, que só podem impor-se no conjunto de um grupo social ou no conjunto da sociedade, depois de um processo de condicionamento cuja eficácia depende de dois fatores: a racionalização e a linguagem, fundamento que nomeia a realidade e/ou o mundo de uma forma peculiar e específica (Bonnewitz, 2003). O u ainda, na linguagem de Bourdieu, a dóxica teria lugar (...) $Q$ uando as estruturas objetivas com as quais se defronta coincidem com aquelas das quais ele é produto, o habitus se adianta às exigências objetivas do campo. Eiso fundamento da forma mais freqüente e mais oculta de censura, qual seja a de colocar em posições, com direito à palavra, agentes dotados de disposições expressivas de antemão "censuradas" por coincidirem com as exigências inscritas na posição (Bourdieu, 1996, p. 72).
} 
Na medida em que o campo científico está mais ou menos submisso às demandas de outros campos, a produção da crença na autonomia do campo científico deve ser considerada, conforme Bourdieu, como o resultado da função ideológica de encobrimento da imposição de interesses específicos dos dominantes como universais. ${ }^{22}$ Desta forma, a autonomia da ciência é falsa, e sua neutralidade, uma farsa. Mais precisamente, a ciência atende aos interesses, econômicos ${ }^{23}$ e políticos da classe dominante. No entendimento de Bourdieu,

...no espaço abstrato da teoria, qualquer campo científico - o das ciências sociais ou da matemática, hoje, ou o da alquimia ou da astronomia matemática do tempo de Copérnico - pode estar situado em algum ponto entre os dois limites representados, de um lado, pelo campo religioso (ou o campo da produção literária), no qual a verdade oficial nada mais é do que a imposição legítima (isto é, arbitrária, e não reconhecida enquanto tal) de um arbitrário cultural exprimindo o interesse específico dos dominantes - dentro do campo e fora dele - e, de outro lado, por um campo científico que baniria qualquer elemento de arbitrário (ou de não-pensado) social e onde os mecanismos sociais realizariam a imposição necessária das normas universais da razão (1983, p. 146).

\footnotetext{
22 Digno de registro é o fato de que o caráter ideológico ou da produção científica como fator de reprodução recebeu atenção como objeto de estudo (H abermas, 1980, 1992) trazendo à luz as relações os vínculos condicionantes do sistema econômico sobre a produção científica - principalmente no que diz respeito ao vínculo do racionalismo científico de cunho positivista com interesses de determinados grupos sociais - bem como o papel desta como legitimadora das estruturas de dominação e de poder. (Sobre este tema ver CO RREA, M aíra. Ciência, Tecnologia e Sociedade. In: Momento, Rio Grande, v. 9, 1996, pp. 59-82; MOREL, Regina. Ciência e Estado - a política científica e tecnológica no Brasil. Q ueiroz, LTDA, 1979)

$23 \mathrm{~N}$ ão seria inoportuno antecipar e sustentar que esta assertiva revela um dos pecados da ciência moderna, isto é, fundamentarse em lei ou leis gerais que se aplicariam a todos os casos na e da realidade sendo, no caso em questão, todos os cientistas. Todavia sua refutação poderia ser encontrada no fato de que nem todos os mestres ou cientistas são estimulados primordialmente por recompensas sociais ou materiais. De uma forma mais precisa, ainda que simplista, segundo Wallerstein: Ninguém ganha 0 prêmio Nobel porque foi incentivado permanentemente pela acumulação de capital (Wallerstein, 2003, p. 96.).
} 
Sendo que, mais especificamente,

... o que está em jogo na luta interna pela autoridade científica no campo das ciências sociais, isto é, o poder de produzir, impor e inculcar a representação legítima do mundo social, é o que está em jogo entre as classes no campo da política. Segue-se daí que as posições na luta interna não podem jamais atingir o grau de independência com relação às posições nas lutas externas que se observa no campo das ciências da natureza. A idéia de uma ciência neutra é uma ficção, e uma ficção interessada, que permite fazer passar por científico uma forma neutralizada e eufêmica, particularmente eficaz simbolicamente porque particularmente irreconhecível, da representação dominante do mundo social. (1983, p. 148).

Desta maneira, caberia, de acordo com Bourdieu, às ciências sociais desvendarem os fundamentos, mormente simbólicos, que sustentam a ignorância da lógica particular que orienta e assegura a dominação de uma parte sobre o todo. Caberia então, no juízo de Bourdieu, a denúncia do caráter ideológico que cumpre a sociologia oficial da ciência que, ao atribuir-lhe qualidades duvidosas de cientificidade, garante a legitimidade da ciência oficial. ${ }^{24} \mathrm{~A}$ sociologia oficial, através da retórica, de estratégias de fechamento ou de denegação ou, até mesmo, do sistema escolar, ${ }^{25}$ assume

240 que seria em primazia, numa linguagem habermasiana, a expressão da autocompreensão inicial na qual a objetivação da teoria obnubilaria a compreensão específica do sentido, sentido este que é a expressão da submissão da consciência ao interesse (Habermas, 1980). Esse interesse, para $\mathrm{H}$ abermas, porquanto servir de base para revelar e criticar a pretensão de neutralidade do enfoque objetivante, pode ser apreendido em seu caráter emancipador, seja da dependência da natureza por sua ação instrumental, seja dos obstáculos ao entendimento pela ação comunicativa (Baumgarten, 1998).

25 U ma proposta diferenciada e alternativa quanto às funções e propriedades do sistema escolar - quando não da edificação de um novo e diferente habitus -, pelo menos no que concerne ao ensino universitário, pode ser apreendida pela proposta de universidade pública apresentada por Boaventura de Sousa Santos (2004). Com a acuidade de revelar os vínculos ou limites do atual sistema universitário com a fase de globalização neoliberal do capitalismo, Santos propõe a superação do atual ethos universitário - produtor de um conhecimento predominantemente disciplinar, relativamente descontextualizado dos contextos de sua aplicação e cuja prioridade e hierarquia de temas, problemas e pesquisas são determinados pelos investigadores - por um outro, pluriversitário, pautado e orientado pelo impacto contextual e social de seu destino; no qual os critérios de relevância e os problemas a resolver são o resultado da cooperação entre pesquisadores e beneficiários, e que promove a interação e articulação com outros tipos de conhecimento - populares, artísticos, camponeses, de origem não ocidental. - consideradosúteis na e para a sociedade. 
a tarefa de forjar a produção da crença e, por decorrência, da reprodução, isto é, de afastar da percepção e da razão qualquer possibilidade de reconhecimento da unilateralidade e parcialidade presentes no paradigma científico hegemônico. Como desvelou Bourdieu

Falsa ciência destinada a produzir e a manter a falsa consciência, a sociologia oficial (de quem a politicologia é, hoje, o mais belo ornamento) deve ostentar objetividade e neutralidade 'ética' (isto é, neutralidade na luta entre as classes cuja existência, por outro lado, ela nega) manter as aparências de uma ruptura categórica com a classe dominante e suas demandas ideológicas, multiplicando os sinais exteriores de cientificidade: temos assim, do lado do 'empírico', a ostentação tecnológica e, do lado da 'teoria', a retórica do 'neo' (florescente também no campo artístico) que imita a acumulação científica aplicando a uma obra ou a um conjunto de obras do passado o procedimento tipicamente erudito da 'releitura' - operação paradigmaticamente escolar de simples reprodução (ou de reprodução simples) feita para produzir, nos limites do campo e de suas crenças, as aparências da 'revolução'. É preciso analisar sistematicamente essa retórica de cientificidade através da qual a 'comunidade' dominante produz a crença no valor científico de seus produtos e na autoridade científica de seus membros (1983, p. 152).

Q uanto mais não seja, o que Bourdieu procura discernir e expor são as condições sociais nas quais e das quais se gera e regenera a produção científica. Segundo ele, mesmo as revoluções científicas, decorrentes de processos de inovação e de outras representações da produção científica, não estariam desconectadas mas, pelo contrário, estariam presas à doxa do campo científico o que demandaria, por seu turno, um esforço, demasiado complexo e profundo, de construção de uma ciência desinteressada. Esta, 
no auditório da Sociologia, seria tão mais desinteressada quanto mais assumisse por objeto tanto as estratégias dos agentes como, em especial, as idéias que condicionam a mobilização dos agentes, isto é, a doxa peculiar a cada campo científico.

\section{Um passo à frente}

Ainda que a perspectiva de Bourdieu revele um certo determinismo na perspectiva de alteração na dinâmica e lógica que permeia o campo científico, não seria demasiado afirmar que seu modo de apreensão desse campo contribuiu para a emergência da consciência acerca da parcialidade e dos vínculos instrumentais da ciência ${ }^{26}$ pertinente ao paradigma racional/ cartesiano, característico da modernidade.

O utrossim, mesmo que possa ser reconhecido - o que lhe daria, à luz de sua própria teoria, elementos de distinção - por integrar um campo na teoria social que discerniu e/ou fez emergir os vínculos entre conhecimento e interesse presentes nas estratégias dos atores em suas buscas por acúmulo de capital simbólico, ${ }^{27}$ Bourdieu não saiu ileso de críticas em face de outras perspectivas de análise. Deste modo, ao minimizar as diferentes possibilidades abertas a partir das interações dos agentes (Capra, 2002) e das distintas configurações discursivas ${ }^{28}$ que podem surgir, deixa de perce-

\footnotetext{
26 A considerar a evolução progressiva da ciência e da técnica modernas e a ausência ou fragilidade das perspectivas sociais utópicas, pode-se afirmar que a transformação da ciência em força produtiva neutralizou seu potencial emancipatório presente na idéia de uma sociedade permeada e orientada pela razão (Santos, 2000).

270 que para Knorr-Cetina apresenta o vício de impor uma interpretação arbitrária, visto que o modelo de mercado científico pressupõe relações de exploração - geração de mais-valia e controle dos meios de produção - o que, segundo ela, não se confirma na análise de grupos de cientistas. A maioria destes não controla os meios de produção nem os resultados ou o produto de seu trabalho (Hochman, 1994).

28 Ao adendarmos a perspectiva proveniente da biologia à análise dos fatores que interferem nas escolhas dos cientistas, teríamos que considerar o caráter variável do funcionamento dinâmico do cérebro que, sendo ao mesmo tempo singular e imprevisível, não registra a presença de códigos neuronais rigorosos que pudessem prescrever percepção e memória representacionais homogêneas. Seu funcionamento, ao contrário, apresenta um repertório diversificado de caminhos possíveis, realizando, dependendo do modo como estabelece seus inputse outputs com o meio, uma enorme gama de combinatórias (Demo, 2002).
} 
ber que suas escolhas não estão tão atreladas às determinações impostas pela estrutura do campo científico ou mesmo de outros campos (Baumgarten, 2001). Ademais, não é incomum aos cientistas, quando defrontados com períodos de crises reconhecidas, recorrerem à filosofia na peregrinação por soluções a seus problemas (Piaget, 1975; Kuhn, 2003). Amiúde, as opções e alternativas, senão as veredas metodológicas - flexíveis e adaptativas -, a densidade de sua motivação e a pertinência de sua curiosidade ${ }^{29}$ têm sua configuração definida a partir do modo pelo qual cada cientista dialoga com seu contexto sociocultural. ${ }^{30} \mathrm{O}$ u seja, ainda que o sujeito cognoscente seja determinado, em certa medida, pela estrutura, isto não quer dizer ser predeterminado. De acordo com Maturana . . . el hecho de que São Paulo conecte todas las rutas hacia todas las ciudades es determinante pero eso no determina que ruta debo escojer (2000, p. 22). Deve-se, por outra parte, segundo Paulo Freire, considerar que a competência em objetivar depende também da emoção. Em seu juízo,

0 medo, a sensibilidade, os afetos e as paixões que eivam a mente curiosa fazem-na epistemologicamente ativa . . . ou, ao contrário, podem castrá-la. Conforme seja o modo com que se convive com o emocional.

\footnotetext{
29 Nesta atmosfera, a curiosidade, mesmo que tenha um histórico indigesto à mesa da evolução da ciência, deve ser considerada como a manifestação do desejo de descobrir, de conhecer. Ela é energia e corpo do conhecimento, pois que, a partir desta este se faz e se renova numa viagem imprevisível e indeterminada. Q uando esta disposição de indagar se torna constante, contínua, diz-se que se tornou habituscuriosandi que, ao incrementar relacional permanentemente o conhecimento, enriquece o processo de aprendizagem que caracteriza a educação por toda a vida. Presente neste relacional está o diálogo entre saber cotidiano e saber científico onde, numa perspectiva Freiriana, a curiosidade deve ser percebida em seu processo de amadurecimento de curiosidade espontânea à curiosidade epistemológica (Assmann, 2004).

$30 \mathrm{Um}$ exemplo deste condicionamento cultural pode ser buscado na forma distinta com que os ocidentais e os japoneses encaminham as questões pertinentes à primatologia, estudada por Haraway (1989). A partir de cada contexto cultural, a interpretação dos primatas tem suas questões fundamentais marcadas pela história cultural pertinente a cada sociedade (Santos, 2000). Em outras palavras, podemos afirmar que os conceitos e as disciplinas, ou mesmo um paradigma, nascem e são condicionados pelo contexto econômico e sociocultural de uma época (Fourez, 1995). O s condicionantes socioculturais que recaem sobre as atitudes, escolhas e métodos dos cientistas - interferindo em seu ritmo e rumo - podem ser considerados, na perspectiva de Luhmann $(1997,1997$ a), como o impacto do meio sobre o sistema científico que, mesmo sendo operacionalmente fechado, é aberto em relação ao seu entorno. Este movimento e/ou interação - acoplamento estrutural para Luhmann - ocorre tanto no diálogo inter-áreas do conhecimento - conhecimento interdisciplinar - como no diálogo entre as mais variadas formas de saber, a qual define os contornos da idéia de ambiência cunhada por Nogueira (2000) ao retomar Espinosa, qual seja, a expressão do diálogo transversal entre as disciplinas; é a síntese da troca das várias modalidades de saber; é o resultado da convivência do plural simultâneo em sucessivas sistematizações, sempre historicamente imperfeitas e provisórias.
} 
Portanto, desenvolver a mente epistemologicamente curiosa orienta-se para desenvolver emocionalmente e racionalmente a capacidade de indagar. Tudo isso é tratamento e cuidado importantes no rumo da educação científica... que é sobretudo uma forma experimental de lidar com ambas emoção/racionalidade sem hierarquizá-las (2000, p. 14-15). ${ }^{31}$

Neste sentido, conforme Hochman (1994), Bruno Latour ${ }^{32}$ foi um dos que procurou minimizar o peso da estrutura sobre as escolhas dos cientistas a partir de sua análise in loco, no laboratório. Tomando por princípio a idéia de 'ciclo de credibilidade', Latour remete a compreensão e explicação do sentido do progresso científico às estratégias de conversão de credibilidade e progresso do cientista, a partir do reconhecimento de seus pares quanto ao valor de sua produção científica. Ainda que tributário de Bourdieu, Latour assinala que menos a estrutura social e mais o volume e intensidade de circulação de sua produção é que influenciam e definem a posição e as estratégias dos cientistas no campo científico.

Para outros, adeptos do construtivismo, a prática científica deve ser compreendida a partir do contexto de sua produção, no qual cada agente a percebe e a ela reage de forma específica. De acordo com Hochman (1994), para Knorr-Cetina, é impensável reduzir a análise do campo científico a uma lógica economicista, sendo esta a pedra angular na orientação do comportamento, então racional e maximizador, do indivíduo. Esta explicação está, segundo esta autora, prisioneira de uma visão de homem identificado com o apetite de acumulação capitalista. Segundo ela, destaca Hochman, o que as incursões aos laboratórios mostram é

\footnotetext{
31 Poderíamos considerar ainda como um movimento de interdependência e interação entre a efetividade - que governa hegemonicamente o campo das escolhas no capitalismo - e a afetividade, carga de sentimentose valores que, se considerados e reforçados, podem contribuir para recolocar a preocupação com a evolução e involução do homem no centro da construção de uma nova humanidade (Nicolescu, 1999).

32 Diga-se de passagem, que, para Latour, nunca fomos modernos, no sentido da cisão homem/natureza. Para ele, a realidade é composta por um conjunto de redesformando sempre novos híbridos de natureza e cultura e nos quais se torna imponderável postular qualquer distinção entre homem e natureza (Wallerstein, 2002).
} 
que os resultados das decisões são socialmente contextuais ou negociados interativamente. Não procedem de um cálculo consciente ou inconsciente, nem podem ser uma conseqüência de propriedades individuais ad quiridas (1994, p. 224).

Por outra parte, não podemos elidir da abordagem de Bourdieu, conforme percebemos, o que a torna mais substantiva, ou seja, o condicionamento sociocultural que recai sobre as escolhas dos cientistas. Se havia alguma dúvida acerca da neutralidade do cientista, despojado de qualquer interesse ou juízo de valor, Bourdieu contribuiu para sua dissipação. N este sentido, ele pode ser alçado à condição daqueles que fizeram do produto da razão científica a própria crítica de sua racionalidade fundante. Por decorrência, ele abriu mais uma janela para o desafio de reconstituir nossas instituições na perspectiva de desenvolver um saber coletivo que, além de insubmisso às relações de poder, seja produto de perspectivas plurais que, quando não, desemboquem em benefícios sociais que minimizem ou eliminem a exclusão.

Apesar disso, as questões colocadas até aqui permitem-nos reconhecer o momento de crise que coloca uma série de questões diante do desafio de compreender o mundo em que vivemos. Q uanto mais não seja, nas palavras de Santos (1987), estamos imersos numa transposição deste paradigma a um outro, ainda emergente, e cuja conformação ainda não apresenta contornos bem definidos. Segundo ele, presenciamos uma transição na qual temos

Em vez da eternidade, a história; em vez do determinismo, a imprevisibilidade; em vez do mecanicismo, a interpenetração, a espontaneidade e a auto-organização; em vez da ordem, a desordem; em vez da necessidade, a criatividade e 0 acidente (1987, p. 28). 
A partir disto, a busca da objetividade das e nas ciências não pode deixar de considerar a necessidade de aproximação entre ciências naturais e ciências sociais, ou mesmo de superação da separação entre ciência e cultura (Nicolescu, 1999), haja vista a interdependência e comunicabilidade entre suas categorias, resultados ou condicionantes. Por decorrência, o valor da ciência deve ser percebido em seu conteúdo processual, ou seja, na busca ininterrupta de superação do erro. É uma combinação de procura, de erro e de aprendizado. Para Bachelard (1984), não há ciência absoluta ou fechada. A idéia de ciência é a idéia de processo. E, enquanto processo, deve estar receptivo às inúmeras formas - ou razões - de percepção da realidade. Para ele, a ciência é a prova da evolução progressiva do pensamento. Nela . . . toda a fronteira absoluta proposta à ciência é sinal de problema mal formulado (1984, p. 22). De forma consoante, na medida em que a realidade é complexa, o conhecimento da mesma deve considerar as propriedades de seus processos biológicos, físico-químicos e psicossociais, ${ }^{33}$ devendo expressar-se, entrementes, por um esforço de linguagem que possa ser compreensível a todos (N ogueira, 2000).

Por outra parte, a superação da dicotomia sujeito/objeto integra a busca da construção de um conhecimento totalizante, porque aberto e sempre inacabado. Isto nos remete a uma nova noção de sujeito que reconhece o protagonismo da natureza, ou seja, que o que pretendemos conhecer se comunica, tem sua linguagem e tem projeto de vida e, não, algo que é somente um autômato, um interlocutor estanque, incomunicável e estúpido a ser quantificado e dominado (Santos, 2000). Implica saber que 0 conhecimento da realidade resulta de uma dinâmica reflexiva na qual a dicotomia, que envolve o dilema da objetividade científica presente na

33 Há pouco mais de 30 anos, a Antropologia nos oferecia um aporte significativo desta perspectiva. Seria então, no curso da evolução humana e em sua diversidade que deveríamos buscar os elementos que pudessem explicar sua complexidade terrificante. Com efeito, para encontrar o homem e a humanidade ter-se-ia que apreender o detalhe e a circunstância, e sua relação com as várias dimensões da organização social e da padronização cultural. E esta é uma tarefa na qual o físico, o químico, o biológico, o social e o cultural devem ser apreciados em conjunto (Geertz, 1989). 
equação conhecimento e interesse, coloca em causa a premissa, por parte do cientista, de um comportamento, mais do que desinteressado, ético.

Esta demanda remete-nos ao reconhecimento de uma realidade complexa na qual sujeito e objeto se retroalimentam num movimento constante de in put e out put em que, não só a ciência deve ser considerada produto e produtora da cultura, como também deve ir em busca de uma síntese de superação da dicotomia sujeito e estrutura. Este ponto de equilíbrio, em termos sociais, apresenta o desafio de diminuir o papel da macrofísica cotidiana sobre as escolhas individuais. ${ }^{34}$ Trata-se de uma necessidade que poderia, nas palavras de Nicolescu (1999), prevenir, senão impedir, que o homem seja colocado na condição de objeto. Para ele, é este desajuste entre a realidade social e realidade individual que leva à fragilidade dos laços sociais e à fragmentação do homem em múltiplas máscaras. Em conseqüência vivemos numa sociedade em que o culto à personalidade reflete o encurralamento do sujeito pela estrutura. De acordo com Nicolescu, o desencontro do homem com seu lugar, sua humanidade perdida é que permitiram a emergência de realidades perversas. Diante disto, este autor questiona:

Como um homem destinado a ser um artista pintor pôde tornar-se um ditador de um grande povo e exterminar friamente um número alucinante de seres humanos? Como outro homem, destinado a ser pároco de aldeia, tornou-se o ditador de um grande país e prendeu e exterminou milhões de seres humanos nos campos de concentração soviéticos? Estes dois tiranos que ensangüentaram a terra poderiam muito bem ter ficado em seus lugares, o de um artista pintor e o de um pároco de aldeia, e passar dias felizes até o fim de

\footnotetext{
34 Esta seria uma premissa para o nascimento de um novo homem a partir da constituição de um novo saber que requer, por seu lado, o sacrifício de certezas habituais e cotidianas a partir do reconhecimento de vários níveis de realidade e de percepção dessa mesma realidade ( $\mathrm{N}$ icolescu, 1999).
} 
suas vidas. Como pode uma concha vazia ser habitada por fantasmas infinitos, como um homem oco torna-se o Deus de um povo? A cisão entre o espaço interior e o espaço exterior de um ser humano pode trazer um esclarecimento interessante a este gênero do processo. Q uando o espaço interno se reduz a nada, o espaço externo pode tornar-se monstruoso (1999, p. 95-96).

Em realidade, o sujeito observador quer conhecer a realidade na qual ele é causa e conseqüência, estrutura e organização. A recursividade presente no diálogo ${ }^{35}$ entre sujeito e objeto é que configura uma das características do pensamento complexo. A integração sujeito/meio é resultado de um processo de comunicação, no qual o conteúdo das mensagens é produto da relação existente entre os que dialogam. N esse processo de interação, quem observa já interfere no objeto observado que, por seu turno, já altera o conteúdo da observação. 0 que existe, na verdade, é a reciprocidade entre sujeitos ${ }^{36}$ (Santos, 2000; M orin, 2003). Esta perspectiva, se levada ao extremo, concorre, conforme Morin, para a compreensão de que (...) Todos os nossos fantásticos mitos que nos garantem uma vida além da morte, vêm de nossa resistência de sujeitos a nosso destino de objetos (2000, p. 324). Isto demonstra que podemos tão somente fazer aproximações à realidade, ${ }^{37}$ nunca apreender sua substância, sua essência. Nas palavras de Santos, comentando o trabalho de Heisenberg,

35 Diálogo este que, na nova retórica pós-moderna, ocorre entre o orador e seus auditórios no qual ambos, por sua vez, apresentam posições intermutáveis e recíprocas tornando o conhecimento gerado multidimensional e progressivo. Com efeito, todo conhecimento produzido é autoconhecimento (Santos, 2000).

$36 \mathrm{Na}$ atualidade, tendo em mira o grau de consumismo presente nas sociedades do capitalismo avançado, os objetos estão cada vez mais carregados de simbolismo e personalização tornando peremptoriamente irreconhecível a distinção entre objeto e sujeito. Por decorrência, conhecer a realidade é conhecer a si-próprio. Neste sentido, todo conhecimento emancipatório é autoconhecimento (Santos, 1987; 2000).

37 Esta mesma realidade apresenta um conjunto variado de níveise um sem-número de níveis de percepção da mesma. Com efeito, uma vez considerando a complexidade do real o conhecimento, para dar conta do objetivo de compreensão do mundo, deve recorrer ao conhecimento transdisciplinar, isto é, um saber que estabelece uma relação de complementaridade entre conhecimento disciplinar, pluridisciplinar e interdisciplinar de modo que se possa estabelecer o diálogo entre todos os campos de conhecimento sem hierarquias preestabelecidas. O u seja, para uma realidade complexa, uma compreensão complexa; para novos e complexos problemas, novos e complexos sistemas de referência (Nicolescu, 1999). 
... sendo estruturalmente limitado o rigor do nosso conhecimento, só podemos aspirar a resultados aproximados e por isso as leis da física são tão-só probabilísticas. Por outro lado, a hipótese do determinismo mecanicista é inviabilizada uma vez que a totalidade do real não se reduz à soma das partes em que a dividimos para observar e medir. Por último, a distinção sujeito/objeto é muito mais complexa do que à primeira vista pode parecer. A distinção perde seus contornos dicotômicos e assume a forma de um continuum (2000, p. 69).

Esta forma de perceber a relação sujeito/objeto remete-nos a outra contradição a ser superada, qual seja, a dicotomia existente entre homem e natureza. 0 desenvolvimento da ciência moderna e o controle da natureza em âmbito planetário revelaram a indissociabilidade entre natureza e cultura. A primeira, enquanto objeto do conhecimento da segunda, foi sempre cultural, o que torna possível asseverar que toda ciência é ciência social (Santos, 1987; 2000; Nicolescu, 1999). Em conseqüência, parece-nosilógico orientar nossos pensamentos e ações como se esperássemos da natureza simplesmente sua reação em resposta ao trabalho humano. Temos que construir uma posição - ética - de comunicação e co-participação entre seres e objetos. Este novo olhar insere-se como ingrediente necessário para uma outra filosofia da Natureza, capaz de estimular o diálogo entre o subjetivo e o objetivo ou entre todos os campos do conhecimento. Nas palavras de Nicolescu

A definição de natureza... não significa nem um retorno ao pensamento mágico, nem um retorno ao pensamento mecanicista, pois ela repousa na dupla afirmação: 1) o ser humano pode estudar a Natureza através da ciência; 2) a Natureza não pode ser concebida fora de sua relação com o ser humano. (1999, p. 67) 
Portanto, um dos nossos desafios é buscar ampliar as fontes de significação e comunicação para além do campo das relações humanas. A idéia seria, na perspectiva de Vandana Shiva, construir a democracia entre todas as formas de vida (Wallerstein, 2002). Isto significa assumirmos uma postura como seres da natureza e, não, na natureza, como se acima dela estivéssemos, ou que ela a nós devesse submeter-se. A liberdade para todos só é possível, assinala Brandão,

Na extensão da idéia de homem ao que é a sua característica mais essencialmente real e manifesta: ser um ser vivo. Ser, melhor ainda, um ser da vida. O que significa: partilhar com outros seres a própria vida. (1994, p. 81)

Em síntese, pensar sobre direitos e liberdade, não mais exclusivamente a partir de seu ponto de vista, mas considerando-o como um dos possíveis dentre um conjunto inexaurível de perspectivas. Estaríamos criando uma condição humana na qual o homem encontraria os limites de seus direitos enquanto espécie nos direitos de existência das outras espécies. É, na verdade, a ampliação e o enriquecimento da noção de liberdade. Brandão lembra:

O sentido da extensão dos direitos à liberdade a tudoo-que-é-vivo deve estar na vida-em-si-mesma e no modo peculiar como cada um de seus seres dela participam, dela partilham e estabelecem com o mundo e com outros seres vivos os seus relacionamentos, a sua comunicação, como tipos de experiências-no-mundo que, ao realizarem a vida a seu... e ao manifestarem-na segundo o seu estilo de ser, possuem em-simesmos o pleno direito da realização da vida-em-simesma. Eis o sentido em que o desaparecimento de uma única espécie viva no planeta quebra a cadeia do fluxo da vida e provoca um dano irreparável a todo o 'sistema da criação' (1994, p. 81). 
Isto posto, a emergência de uma nova forma de apreender a realidade requer que o conhecimento científico conviva com outras formas de conhecimento, ou com o reconhecimento da existência de sistemas incompletos, num movimento espiral de enriquecimento recíproco. Neste sentido, Santos (1987) ressaltou a aproximação e entrelaçamento que deve haver entre conhecimento científico e senso comum. Segundo ele, existem várias formas de percepção e apreensão da realidade, cada qual com seu volume de conhecimento e ignorância. Conforme Santos, no contexto do paradigma emergente, temos que considerar que;

Todo o conhecimento implica uma trajetória, uma progressão de um ponto ou estado $A$, designado por ignorância, para um ponto ou estado $B$, designado por saber. As formas de conhecimento distinguem-se pelo modo como caracterizam os dois pontos e a trajetória que conduz de um ao outro. Não há, pois, nem ignorância em geral nem saber em geral. Cada forma de conhecimento reconhece-se num certo tipo de saber a que contrapõe um certo tipo de ignorância, a qual, por sua vez, é reconhecida como tal quando em confronto com este tipo de saber. Todo o saber é saber sobre uma certa ignorância e, vice-versa, toda a ignorância é ignorância de um certo saber ${ }^{38}(2000$, p. 78)

Deste modo, o enriquecimento do conhecimento sobre a realidade demanda não somente a relação de interdependência entre a razão e a especulação $0^{39}$ mas, inadvertidamente, uma interpenetração e um diálogo

\footnotetext{
38 Neste contexto, o maior erro da abordagem disciplinar, ainda que reconheçamos sua importância, é se voltar para si mesma num movimento incessante na busca da ultra-especialização, pois, mais do que conhecimento o que se está gerando são espaços de ignorância, de involução, na medida que não se reconhece a multiplicidade de questões impensadas a partir das interações com outras perspectivas disciplinares.

390 que requer, por sua parte, a superação do engodo da divisão entre ciência e filosofia. Ao contrário, somente a complementaridade entre ambas pode permitir uma aproximação com os fenômenos complexose plurais que configuram a realidade. Além do que, qualquer sonho ou interpretação metafísica refere-se a este mundo, portanto, de realidades concretas. Por outro lado, todo empirismo busca e se utiliza de explicações e interpretações transitórias, senão alternativas, porquanto socialmente construídas. Da unidade entre ciência e filosofia resulta o encontro da verdade com a virtude, do que se é com o que se deve ser (Piaget 1975; Wallerstein, 2002).
} 
entre todas as formas de saber e/ou conhecimento. E esse conhecimento deve ser transdisciplinar, aquele que busca construir um saber que está nas disciplinas, entre as disciplinas e além de qualquer disciplina, pois que a compreensão do mundo presente requer a unidade do conhecimento e dos seres (N icolescu, 1999). Com efeito, a combinação de saberes sugere ser um dos ingredientes metódicos para a tarefa de elaborar análises cada vez mais substantivas em relação à realidade. Diante de um mundo permeado por incertezas e injustiças, pondera Wallerstein, temos que estabelecer pontes entre as mais variadas perspectivas e saberes, de modo a termos mais segurança quando de nossas escolhas ou decisões. E esses saberes têm que circular num ambiente de igualdade. De acordo com ele,

... o saber envolve escolhas - as escolhas de todos são importantes, e é claro as escolhas dos atores sociais, entre eles os estudiosos. Toda escolha envolve decisões sobre o que é materialmente racional. Não podemos mais sequer fingir que estudiosos possam ser neutros, isto é, despojados de sua realidade social. Mas isto não quer dizer que tudo pode. Significa, isto sim, que temos que pesar todos os fatores cuidadosamente, em todos os domínios, para tentar chegar a decisões ótimas. E isto significa, por sua vez, que temosde conversar uns com os outros, e fazê-lo como iguais. Sim, alguns de nós têm saberes mais específicos do que outros sobre áreas de interesse específicas, mas ninguém, nenhum grupo, tem todo o saber necessário para tomar decisões materialmente racionais, mesmo em domínios relativamente limitados, sem levar em consideração o saber dos outros, fora desses domínios. Sim, não há dúvida, se precisasse de uma neurocirurgia, eu ia querer o neurocirurgião mais competente. Mas neurocirurgia competente envolve igualmente certos aspectos jurídicos, éticos, filosóficos, psicológicos e sociológicos. E uma instituição como o 
hospital precisa combinar esses saberes numa visão materialmente racional. Por outro lado, asopiniões do paciente não são irrelevantes. Mais do que ninguém, é o neurocirurgião que precisa sabê-lo, como o sociólogo e o poeta. Habilidades não se dissolvem num vazio informe, mas são sempre parciais e precisam ser integradas com outras habilidades parciais (2002, p. 300).

N esta perspectiva, a ciência moderna não pode mais ser considerada a única explicação possível da realidade. Esta compreensão não é imatura entre nós. Mannheim, em meados do século passado, chamava atenção sobre a não exclusividade da razão científica diante do desafio de compreender e explicar a realidade. Conforme ele,

... nosso desenvolvimento científico moderno, baseado no pensamento 'inventivo' e em última análise nas necessidades da técnica, tende a obscurecer o fato de que o contato físico e psíquico e a percepção de um objeto proporcionam uma fonte de conhecimento igualmente válida. Não é, absolutamente, verdade que estes não proporcionem conhecimento - o conhecimento que obtemos através deles é apenas um tipo de conhecimento totalmente diferente do conhecimento abstrato inventivo, que procura 'produzir' e 'usar' o objeto, e portanto o concebe em termos funcionais. [...] 0 conhecimento baseado na intuição, por outro lado, mantém-se muito próximo do objeto e tenta obter suas informações do objeto tal como o encontra (1962, p. 181)

Neste sentido, se abdicarmos da tarefa de captar toda a magnificência produzida a partir das diferentes formas de pensar, agir, sentir, expressas, por exemplo, na vida cotidiana, não poderemos compreender seus porquês, suas contradições e seu futuro possível. De outra parte, se as generali- 
zações são importantes para termos uma visão panorâmica da realidade, trazem consigo também o ônus de permitir que se ofereça uma atenção demasiada aos aspectos macroestruturais como elementos explicativos dos desdobramentos dos fenômenos sociais. Não queremos, ao afirmar isto, negar o valor das análises estruturais, mas chamar a atenção - sem cair exclusivamente no atomismo - para o cenário no qual efetivamente se desenvolvem as relações sociais, a vida cotidiana.

No entanto, se a realidade possui sua mais viva expressão na vida cotidiana, é porque esta se apresenta como um mundo intersubjetivo e intra-subjetivo. Por outro lado, a rotina da vida cotidiana traz consigo a dúvida a respeito da realidade. 0 u seja, impede sua problematização. Esta só se dá a partir de um novo conhecimento que, contraposto ao senso comum, rompe a continuidade da realidade cotidiana. N este sentido, entendemos que é o acervo social do conhecimento que levamos à nossa prática cotidiana, que irá estabelecer nossa relação com o senso comum e, portanto, com sua superação. A questão central para nós, concordando com Berger e Luckmann, é reconhecer que

O mundo da vida cotidiana proclama-se a si mesmo e quando quero contestar esta proclamação tenho de fazer um deliberado esforço, nada fácil. A transição da atitude natural para a atitude teórica do filósofo ou do cientista ilustra este ponto $(1983$, p. 41)

Com efeito, existem outros saberes e modos de conhecimento - as próprias práticas sociais, por exemplo - não redutíveis ao conhecimento científico $^{40}$ (N unes, 2004). De acordo com esta visão, a ciência deve valerse das virtudes inerentes ao senso comum - unidade entre causa e intenção; prático, pragmático e espontâneo; contemporâneo e complementar à 
experiência cotidiana; evidente; interdisciplinar e imetódico - de maneira que a vida da experiência esteja condicionada, senão dirigida, pela necessidade da experiência da vida. Em realidade, para Santos

A ciência pós-moderna, ao sensocomunizar-se, não despreza o conhecimento que produz tecnologia, mas entende que, tal como o conhecimento se deve traduzir em auto-conhecimento, o desenvolvimento tecnológico deve traduzir-se em sabedoria de vida (1987, p. 57).

Esta questão remete-nos ao cuidado que temos que ter quanto ao perigo que corremos - enquanto pretensamente intelectuais- de utilizarmonos de categorias analíticas inadequadas e/ou privilegiar generalizações. Ao desconsiderarmos toda a diversidade e profundidade implícitas na e da vida cotidiana, distanciamo-nos, afetivamente, de uma interpretação que considere, mais fielmente, saberes outros produzidos e ou gestados no dia- adia da prática social (Santos, 1997). Entretanto não podemos confundir diálogo e troca de saberes com a substituição de um saber pelo outro. A realidade, em toda sua infinita complexidade não pode ser apreendida a partir de uma única perspectiva ao mesmo tempo em que não pode prescindir dela. Na perspectiva de Fourez,

... o cientista não possui um saber fundamentalmente diferente dos outros. Todos se referem a um corte preciso que é o de seu ponto de vista e que todos conhecem bem; e todos desejam possuir uma relação com outros saberes, outras perspectivas. Os diferentes tipos de saber aparecem então como esclarecimentos localizados que se deve pôr em contato[. . ] (1995, p. 134).

O que se está a propor é uma ruptura com a monocultura epistemológica, em grande medida imposta pela ciência moderna, na pers- 
pectiva da maximização da contribuição de cada saber em relação a explicação e compreensão da realidade. Esta última não pode ser reduzida ou reproduzida numa única perspectiva. Afinal, os saberes não estão imunes ao princípio da incompletude (Santos, 2005). Por exemplo, se a análise da dinâmica do comportamento das classes populares em sua relação com 0 todo do complexo societário se der a partir de um campo conceptual que privilegie termos como falsa consciência, alienação, ignorância, arcaísmo, atraso, etc., estaremos desconsiderando outras formas de resistência e de saberes que não passam necessariamente por algum ideal de organização coletiva. De outra parte, corremos o risco de sermos alvos da indiferença, porque incapazes e insensíveis de perceber a riqueza implícita na lógica interna da vida das classes populares.

Esta sabedoria seria, ao ser considerada, um passo adiante na superação daquilo que Bourdieu denunciou como a eleição do todo pela perspectiva de uma parte. Em outras palavras, as considerações relativas ao todo devem estar condicionadas pela relação deste com suas partes inerentes. Isto é, o conhecimento de determinada realidade e ou fenômeno pressupõe a assunção de sua referência inconteste com esferas circundantes, as quais contribuem para a configuração, movimento e/ou substância dessa mesma realidade.

Por outro lado, a compreensão da totalidade ${ }^{41}$ imanente e transcendente, não deve abdicar de considerar o conhecimento presente, em sua própria natureza, ainda que a mesma seja decorrente da relação com outras partes e, até mesmo, de sua relação com o todo. Por conseguinte, e em conformidade com a disposição do que foi apregoado até aqui, o significado do que é multidisciplinar e interdependente deve invocar o entendimento de que a explicação e a compreensão do mundo cognoscível não

41 Exercício que Mannheim (1972) já havia preenchido de conteúdo ao denunciar as insubstâncias do relativismo e ao prescrever a necessidade de consideração das propriedades do relacionismo para a busca e compreensão da totalidade. 
podem, sob o risco de não correspondência entre conhecimento e realidade, abrir mão de estabelecer os conteúdos cunhados a partir das relaçõese propriedades estabelecidas entre cada parte e o todo. Em síntese, esta tarefa nos remete a aceitar o fundamento de Pascal, ${ }^{42}$ que pondera que,

Como todas as coisas são causadas e causadoras, ajudadas e ajudantes, mediatas e imediatas, e todas são sustentadas por um elo natural e imperceptivel, que liga as mais distantes e as mais diferentes, considero impossível conhecer as partes sem conhecer o todo, tanto quanto conhecer o todo sem conhecer, particularmente, as partes.

Em conseqüência, esta ligação entre o todo e as partes, entre o micro e o macro, entre o global e o local, entre o imanente e o transcendente, entre a ordem e a desordem, entre o conhecimento e o desconhecimento está impregnada de complexidade. A necessidade da compreensão da multidimensionalidade dos fenômenos demandou que saberes e culturas antes singulares, antagônicas ou desunidas viessem a ter que dialogar ou, mais do que isto, a restabelecer uma unidade perdida a partir da fragmentação e especialização inerentes ao paradigma da modernidade. Em realidade, começa a ganhar força, forma e conteúdo uma concepção de abordagem da realidade que leva em consideração a idéia de que esta última é produto de uma complexidade, de cuja totalidade, paradoxalmente, só se conhece uma parte. Em síntese, que almeja ser capaz de reconhecer que a totalidade da complexidade é imponderável e, como tal, deve constituir-se na energia que a coloca em movimento. Em outras palavras, o desafio que a complexidade suscita é o da incompletude do conhecimento. Estes são somente alguns ingredientes do que podemos chamar de problema da complexidade, isto é, termosque lidar com a incompletude, portanto, infinitude, do conhecimento.

42 PASCAL apud MORIN, Edgar. A cabeça bem feita - repensar a reforma, reformar o pensamento. Rio de Janeiro: Bertrand Brasil, $2000^{a}$, p. 88. 
Trata-se, por suposto, de um ajuste de contas interminável com o desconhecido, com a inconsciência ainda contaminada pelas amarras impostas pela hegemonia de concepções pormenores, porquanto interessadas, ou inabitada pelo conhecimento. 0 papel da ciência, por sua vez, não é, como outrora, impor-se ou subjugar o mundo, mas dialogar com ele. E, para tanto, temos que encontrar caminhos nos quais a produção e o progresso do conhecimento sejam dados, menos pelas respostas que a ciência apresenta e mais pelas dúvidas que inaugura. E ele será tão mais compreensivo se for produto da comunicação entre cultura científica, cultura humanista - filosófica - e cultura dos cidadãos, num processo que se pode chamar de co-construção do conhecimento (Nunes, 2004). Tal é o desafio do método da complexidade, nos termos que o pronunciou Morin. Sua idéia de método sintetiza, de certa forma, o que estivemos discutindo até agora. De acordo com ele,

O método da complexidade pede para pensarmosnos conceitos, sem nunca dá-los por concluídos, para quebrarmos as esferas, para restabelecermos as articulações entre o que foi separado, para tentarmos compreender a multidimensionalidade, para pensarmosna singularidade com a localidade, com a temporalidade, para nunca esquecermos as totalidades integradoras. $\dot{E}$ a concentração na direção do saber total, e, ao mesmo tempo, é a consciência antagonista e, como disse Adorno, 'a totalidade é não-verdade'. A totalidade é, ao mesmo tempo, verdade e não-verdade, e a complexidade é isso: a junção de conceitos que lutam entre si $\left(2000^{b}\right.$, p. 192).

De qualquer modo, para a sociologia, como para qualquer ciência, uma questão é essencial para a validação do próprio conhecimento elaborado. Referimo-nos à questão do método. Neste sentido, os métodos na Sociologia devem possibilitar um grau máximo de objetivação no tratamento 
de seus objetos. Como ciência que se propõe a explicar o "como" e o "porquê" dosfenômenos sociais, apresenta métodos que permitem a apreensão tanto do macrossociológico - estruturalismo ou holismo - quanto do microsociológico - método compreensivo - ou, até mesmo, através da busca das possíveis relações entre microcomportamentos e fenômenos agregados - o individualismo metodológico.

Por outra parte, se a análise de Bourdieu e as outras perspectivas apresentadas acima sugerem que a compreensão do mundo não pode ficar sujeita ao pensamento e interpretação parciais da realidade, esta pode, muito menos, estar circunscrita à leitura que, o senso comum - ainda que sua contribuição faça diferença - elabora sobre ela. Enquanto a primeira nos conduz à dominação e à falsa ciência, a segunda fica presa às percepções da intuição do observador. Tanto o senso comum como a sociologia oficial ou espontânea, em que pesem suas propriedades e contribuições, criam uma espécie de armadilha para o cientista - o sociólogo ${ }^{43}$

Nesta perspectiva, a ilusão do conhecimento do social - e da ação humana que a sustenta - pode ser descrita, segundo Bourdieu (1987), como não-consciência. Sua identificação e superação se tornam condições para a constituição da ciência sociológica. A este princípio de não-consciência, afirma Bourdieu, impõe-se outro: a teoria do conhecimento social. Ela consiste na captação lógica de um sistema de relações objetivas, no qual os indivíduos se acham inseridose sua organização proporciona a explicação para as ações dos indivíduos. Nesta perspectiva, pondera ele

Un objeto de investigación, por más parcial y parcelario que sea, no puede ser definido y construído sino en

43 Nesta tarefa de romper com este saber doxológico, é importante retomarmos os apontamentos que fizeram Durkheim, Marx e W eber a este respeito. 0 primeiro alertou-nos para os perigos do artificialismo, lembrando que a natureza dos fatos não depende da arbitrariedade individual ou de onde derivam as relações necessárias. Marx afirmou que os homens fazem a história em condições dadas, ou seja, que os homens mantêm relações independentes de sua vontade. De outra parte, W eber assinalou as intenções subjetivas dos atores no sentido cultural das ações. Somente com rigor metodológico, podemos descer aos alicerces da realidade e descobrir de que material eles são feitos. 
función de una problemática teórica que permita someter a un sistemático examen todos los objetos de la realidad puestos en relación por los problemas que le son planteados (1987, p. 54).

A questão que está em jogo aqui é qual o mecanismo que possibilita esse "sistemático exame de todos os aspectos da realidade". Em resposta a esta indagação regressamos ao método. Este deve ser considerado como forma de conhecer e como conhecimento, como estratégia para conhecer e como estratégias para a ação (Morin, 2003). É ele que possibilita uma leitura - ou releitura - do mundo, contribuindo para que ela tenha sentido a partir mesmo do aguçamento e aprofundamento da capacidade crítica do sujeito cognoscente. Isto pode ser confirmado pelo exemplo simples que nos apresenta N icolescu (1999). Segundo ele,

As recentes experiências feitas pelo Prêmio Nobel de física Leon Lederman com crianças dos bairros menos favorecidos de Chicago (. . .). O professor Lederman primeiro convenceu alguns professores da escola secundária a se formarem em novos métodos de aprendizagem da física baseados em jogos, no tocar diferentes objetos, na discussão entre os alunos para descobrir o significado das medidas, fazendo os diferentes órgãos dos sentidos intervirem - visão, tato, audição tudo isso numa atmosfera de prazer e alegria, ou seja: tudo o que é mais distante possível do aprendizado formal das matemáticas e da física. Eo milagre acontece: as crianças provenientes das famílias mais pobres, onde reinam a violência, a falta de cultura e o desinteresse pelas questões habituais das crianças, descobriram através dos jogos, as leis abstratas da física. Estas mesmas crianças tinham sido decretadas, um ano antes, incapazes de compreender qualquer abstração. Aliás, é interessante assinalar que as maiores dificuldades da operação e, nem é preciso dizer, a maior parte 
do seu custo, foram devidas à resistência dos professores: eles tinham muita dificuldade em abandonar seus métodos antigos. A formação dosformadores foi mais longa e mais difícil do que o trabalho com as crianças (1999, p. 137-138)

Foi em função de uma objetividade na busca destas conexões de sentido das ações humanas que, os "clássicos" da Sociologia - Marx, Weber e Durkheim - sugeriram métodos para lidar com os objetos desta ciência. Neste ponto reside também a importância da vigilância epistemológica. É através dela que o sociólogo faz a distinção entre saber imediato e discurso científico, tanto quanto estabelece as possíveis complementaridades entre ambos. Para Bourdieu, ela se constitui na exigência e . . . una explicación metódica de las problemáticas y prinicipios de construcción del objeto que están comprendidos tanto en el material como en el nuevo tratamiento que se le aplica (1987, p. 56).

Por outro lado, este controle epistemológico pode ser dificultado ou facilitado pela linguagem. De uma parte, porque não é construindo um discurso sofisticado que o sociólogo vai impedir a penetração dos pré-saberes ou constituir antíd oto à presença de visões parciais no discurso sociológico. As ciências sociais para se diferenciarem das interpretações particulares, artificiais ou superficiais do funcionamento social, diria Bourdieu, devem ancorar na explicação total dos esquemas da explicação sociológica, ou seja, estabelecer um controle semântico. De outra parte, devemos encontrar a positividade na fuga constante da interpretação baseada na observação instantânea. Esta deve, por seu turno, ser acompanhada de uma pontualidade metodológica, sem a qual não alcançaremos a objetividade científica, postando-nos como vítimas das inseguranças geradas por interpretações particulares, quando não obtusas e falseadoras da realidade. 


\section{Diálogos impertinentes}

De qualquer forma, pelo exposto, não devemos inferir que qualquer aproximação com a realidade tenha sua substância circunscrita à atenção às demarcações que destacamos neste espaço. É possível considerar que existem categorias ainda não pensadas, porquanto ainda inauditas que, a partir de uma perspicácia, senão curiosidade epistemológica, devem ser alçadas à aventura do conhecer. São, em verdade, categorias como, por exemplo, o acaso, a desordem, a incerteza, a organização, nas quais, na cultura, podem impor limitações às partes ou mesmo potencializá-las e desenvolvêlas. Deste modo, consideramos que não há conclusão que possa requerer pertinência ou conveniência. Q ualquer que fosse, ela estaria presa à necessidade de se transformar em miríade deste debate, o que estaria fora do alcance deste autor e muito além das fronteiras deste espaço.

0 que apresentamos acima foi uma tentativa de revelar um diálogo impertinente que envolve a realidade e os saberes que, sendo parte desta mesma realidade, reivindicam a possibilidade de refleti-la. Esta posição, apesar de seu longo período de crise, ainda é majoritária e hegemonicamente ocupada pelos cânones da ciência moderna. Alias, como poderíamos explicar os desenvolvimentos e progressos societários, apesar de seus refluxos sociais e morais, da sociedade global. Mais do que nunca, o desenvolvimento tecnológico e científico se tem colocado a serviço da reprodução e produção da lógica do capital.

A perspectiva de denúncia dos mecanismos que ocultam esta realidade talvez possa ser considerada como uma das contribuições significativas de Bourdieu. Ele denunciou ${ }^{44}$ como o campo científico é dominado por interesses singulares e por determinados mecanismos para assim não serem percebidos. No entanto, Bourdieu, apesar de reconhecer a interferência 
das lutas presentes no campo social, no campo científico, bem de como 0 arbitrário cultural presente na lógica desse campos, não considerou a presença e importância de outras formas de saber, tanto como percepção da realidade quanto como possibilidade de aperfeiçoamento do próprio conhecimento científico. Neste sentido, um reencontro do saber científico com as diferentes e diversas culturas que atravessam o humano numa perspectiva de superar a comunicação atrofiada da primeira com esta, a considerar a hegemonia dos condicionantes econômicos. Destarte, o enriquecimento científico, senão uma abordagem transdisciplinar da realidade, requer seu diálogo, como, por óbvio, uma linguagem, com a infinita diversidade presente em um mundo cultural diverso. Esta compreensão fica mais clara a partir da visão de Nicolescu.

As diferentes culturas são as diferentes facetas do humano. 0 multicultural permite a interpretação de uma cultura por outra; o intercultural, a fecundação de uma cultura por outra, enquanto que o transcultural assegura a tradução ${ }^{45}$ de uma cultura para qualquer outra cultura, pela decodificação do sentido que liga as diferentes culturas, embora as ultrapasse. A linguagem transcultural, que torna possível o diálogo entre todas as culturas e que impede sua homogeneização [. . .] (1999, p. 110-111).

As prescrições e preocupações de Bourdieu para com a objetividade científica devem ser apreendidas dentro da compreensão de que o saber científico, mais do que diferenciado, é um saber hierarquicamente superior.

\footnotetext{
450 s processos de tradução é que permitiriam a conversão dos saberes científicos em saberes cotidianos, bem como alçar problemas deste último a objeto das preocupações dos primeiros (Fourez, 1995). Essa tradução deve poder ser pensada ainda dentro da perspectiva da ecologia dos saberesna qual, a partir do intercâmbio e comunicação de saberes, busca-se a maximização da contribuição de cada saber no desafio da compreensão da realidade. M ais do que isto, a tradução deve ser percebida como um diálogo e confronto de culturas que busca, a partir de valores mínimos compartilhados, a inteligibilidade recíproca entre os saberes e experiências do mundo, na perspectiva de construir uma nova concepção de emancipação social alternativa à globalização neoliberal (Santos, 2005).
} 
Em suas análises, apesar de reconhecer a necessidade de inter-relacionar saberes, ele não reconhece que outras formas de saber que não o científico podem ser mais ap ropriadas na abordagem de determinados níveis da realidade e que se constituem como percepções e conhecimentos cuja pertinência permitem uma compreensão mais próxima do que seja a realidade. Em outras palavras, Bourdieu, ao decretar a superioridade do saber científico, coloca em segundo plano os saberes ${ }^{46}$ do corpo e dos sentimentos, ambos elementos que, aliados à cognição, garantem a unidade entre efetividade e afetividade, entre ciências da natureza e ciências do homem, entre saber científico e saber que brota da experiência da vida. Quanto mais não seja, há que se reconhecer que o verdadeiro espírito científico está baseado no questionamento constante e muito mais dependente da qualidade das informações do que propriamente da quantidade das mesmas (Nicolescu, 1999; Lima, 2002).

O utrossim, a vigilância epistemológica defendida por Bourdieu, ainda que necessária, não é, seguramente, suficiente. A Sociologia não pode abdicar da tarefa de apontar conteúdos ao universo incontornável das possibilidades. Trata-se, em realidade, da necessidade da presença de uma imaginação sociológica. Em nosso juízo, aquela mesma imaginação desejada por Wright Mills (1975), que prescrevia ao cientista social a necessidade da construção de pontos de vista diversificados o bastante que pudessem aproximar-se, em alcance e profundidade, da variedade humana e da complexidade da vida. Por decorrência, estaríamos diante do sentido político de sua atuação que, mais do que orientado pelos valores da verdade, da liberdade e da relevância social, estaria direcionado, ainda que não exclusivamente, às questões públicas de nosso tempo. ${ }^{47}$

46 Responsáveis por permitir o acesso a representações distantes, ainda que não inatingíveis, do alcance das categorias científicas.

47 Estas, conforme Tavares dos Santos, podem ser resumidas. . . pela multiplicidade e fragmentação, pelo universalismo e por identidades restritas, em âmbito local, regional e mundial. Vários são os exemplos: precarização do trabalho; a crise da educação; as múltiplas formas de violência; a sociedade da informação e a exclusão digital; a seletividade social e a exclusão 
A imaginação sociológica deve vivificar este desafio no compromisso, tanto de identificação das necessidades e preocupações sociais contemporâneas - desde suas causas até seus desdobramentos - como, sobretudo, apresentar orientações e perspectivas que conduzam a um pensamento que contribua para uma reinvenção da emancipação social (Santos, 2005), ou mesmo, para uma inovação nos termos do contrato social (Tavares dos Santos, 2001).

Nesta preocupação de interpretar a relação entre conhecimento e realidade, deparamo-nos com perspectivas que sugerem mudanças em relação à forma como as ciências devem ser apreendidas em sua condição de ser e estar. Diante dos argumentos que provocaram a crise da ciência moderna, principalmente de sua limitação para apreender a complexidade da realidade, outras concepções, baseadas na indistinção entre sujeito e objeto, entre homem e natureza, estão a inaugurar uma nova forma de diálogo entre a ciência e a sociedade. Esse diálogo, porque impertinente, faz-se inquieto e infinito na procura das propriedades que constituem a realidade, o que, por vezes, deve ser buscado nos interstícios ou intersecções que permeiam as várias percepções ou áreas do conhecimento. 0 atual momento de crise societária no qual estamos mergulhados revela que o mundo está mudando, mas que, todavia, isto não quer dizer que esta mudança seja para melhor. Pelo contrário, as tendências atuais indicam uma perspectiva mais do que sombria.

Esta é a realidade que impõe aos cientistas uma dupla e inarredável provocação, qual seja, aliar o trabalho de explicar a realidade à capacidade de "impensar", isto é, tentar desamarrar-se de antigas tradições e categorias que nossa herança cultural nos legou, de modo a podermos introduzir

social; as discriminações por gênero; os vários racismos; a pobreza, a miséria; a degradação do meio ambiente; e a fome (2001, p. 172-173). Acrescentaríamos ainda, por nossa conta, um certo esgotamento das perspectivas utópicas cuja fatalidade, em certa medida, o Fórum Social M undial tem a pretensão de ser um antídoto. 
novos insumos, tanto em nossas análises quanto para o cenário de nossas alternativas históricas (Wallerstein, 2002). Destarte, em função do desafio da construção de interdependência e reciprocidade dos saberes presentes na sociedade, precisamos, mais do que nunca, de uma imaginação científica que inclua, em suas teorias, métodos e procedimentos o problema, ainda insuficientemente refletivo, de enriquecimento do conhecimento científico por outras formas de conhecimento. $M$ ais do que criar um homem novo, o homem precisa nascer de novo (Nicolescu, 1999).

Sua importância reside, entre outras coisas, em procurar, sem cair no risco do relativismo, envolver perspectivas de análise mais totalizantes, portanto, uma preocupação com a indistinção relativa entre ciência social e ciência natural, entre homem e natureza, entre saber científico e outros saberes, entre sujeito e objeto, entre ciência e sociedade. 0 fato é que estes são diálogos cuja reciprocidade produz uma realidade de maior riqueza na concepção de realidade. São diálogos que, por impertinentes, resgatam uma necessidade, em tempos difíceis, de que o pensamento possa ser testemunho de uma consciência capaz de produzir idéias, mais do que pertinentes, úteis de modo a possibilitar uma reconstrução de nossa estrutura de pensamento (Wallerstein, 2003), capaz de nos orientar em nossas escolhas e em nossas lutas por concretizar a dignidade humana.

N esta perspectiva, a construção de um conhecimento que não esteja submetido aos atuais padrões de eficácia e eficiência que comandam a sociedade de consumo requer a religação da ciência com o mundo da cultura, na perspectiva da construção de uma linguagem universal através dos valores compartilhados. Não se quer, com isto, que se abandone a razão. Pelo contrário, o que se quer é fazer da razão uma aliada na busca do possível, da probabilidade, da criatividade. Por demais, tal conhecimento deve estar centralizado na satisfação e desenvolvimento do humano e não das coisas ou do mercado. A criação do saber atual ensina o que, como e 
onde consumir. 0 desafio é construir sentido e satisfação na vida, a partir do aprender a saber criar, a ter na criatividade, adubada por todas as formas de saber, a matriz de uma nova racionalidade que ajude, mais do que compreender a realidade, a inaugurar atitudes e estruturas sociais capazes de conferir sentido e satisfação à vida. E, se nesta caminhada nos reconhecermos como poucos, estaremos, de alguma forma, antecipando o que virá. Entrementes, ninguém melhor que Thiago de Mello para aproximar, em consciência, o que somos de nosso desejo de futuro.

\section{Para os que virão}

Como sei pouco, e sou pouco, faço o pouco que me cabe me dando inteiro. Sabendo que não vou ver o homem que quero ser

Já sofri o suficiente para não enganar a ninguém: Principalmente aos que sofrem na próxima vida, a garra da opressão, e nem sabem.

Não tenho o sol escondido no meu bolso de palavras. Sou simplesmente um homem para quem já a primeira e desolada pessoa do singular - foi deixando, devagar, sofridamente de ser, para transformar-se - muito mais sofridamente - na primeira e profunda pessoa do plural.

Não importa que doa: É tempo de avançar de mão dada com quem vai no mesmo rumo, mesmo que longe ainda esteja de aprender a conjugar o verbo amar.

É tempo sobretudo de deixar de ser apenas a solitária vanguarda de nós mesmos. Se trata de ir ao encontro. (Dura no peito, arde a límpida verdade dos nossos erros.) Se trata de abrir o rumo.

Os que virão, serão povo, e saber serão, lutando. 


\section{Referências}

ANDRADE, Carlos Drumonnd de. Verdade. In: ANDRADE, Carlos Drumonnd de. Corpo. 10 ed. Rio de Janeiro: Record, 1987.

ASSMANN, Hugo. Curiosidade e prazer de aprender - 0 papel da curiosidade na aprendizagem criativa. Petrópolis, RJ: Vozes, 2004.

BACHELARD, Gaston. A epistemologia. Lisboa: Edições 70, 1984.

BAUMGARTEN, Maíra. Habermas e a emancipação: rumo à democracia discursiva? In.: Teoria Social_- Desafios de uma nova era. Cadernos de Sociologia/Programa Pós-Graduação em Sociologia, v. 10, Porto Alegre: UFRGS, 1998. 178 p. p. 137-178.

- Globalização e Ciência \& Tecnologia no limiar do século XXI: os anos 90 no Brasil. In: BAUMGARTEN, Maíra (org.). A Era do Conhecimento: Matrix ou Agora? Porto Alegre/Brasília: Ed. Universidade/UFRGS/Ed. UnB, 2001. 263 p. p. 89-119. 2002.

Conhecimento, Planificação e Sustentabilidade. Porto Alegre/Mimeo,

BERGER, Peter \& LU CKMAN N, Thomas. A construção social da realidade. Petrópolis, RJ: Vozes, 1983.

BO N NEWITZ, Patrice. Primeiras lições sobre a sociologia de Pierre Bourdieu. Petrópolis, RJ: Vozes, 2003.

BOURDIEU, Pierre. O campo científico. In.: ORTIZ, Renato (O rg.). Pierre Bourdieu: Sociologia. São Paulo: Ática, 1983. 191 p. p. 122-155.

. Esboço de uma teoria da prática. In.: O RTIZ, Renato (O rg.). Pierre Bourdieu: Sociologia. São Paulo: Ática, 1983. 191 p. p. 46-81.

. (et al). El oficio de sociólogo. México: Siglo XXI, 1987.

. 0 poder simbólico. Lisboa: Difel, 1989.

. A Reprodução. Rio de Janeiro, RJ: Francisco Alves Editora, 1992.

. Razões Práticas - Sobre a teoria da ação. Campinas, SP: Papirus, 1996. 
. A economia das trocas lingüísticas. São Paulo: Edusp, 1996ª.

. Cosas Dichas. Barcelona: Gedisa, 2000.

Meditações Pascalianas. Rio de Janeiro: Bertrand. Brasil, 2001.

A Produção da Crença - contribuição para uma economia dos bens simbólicos. São Paulo: Zouk, 2002.

CAPRA, Fritjof. As conexões ocultas - Ciência para uma vida sustentável. São Paulo: Cultrix, 2002.

CORREA, Maíra. Ciência, Tecnologia e Sociedade. In.: Momento, Rio Grande, v. 9, 1996. p. 59-82.

DEM O, Pedro. Complexidade e Aprendizagem - A Dinâmica não Linear do Conhecimento. São Paulo: Atlas, 2002.

FO UREZ, Gerard. A Construção das Ciências: introdução à filosofia e à ética das ciências. São Paulo: U NESP, 1995.

FREIRE, Paulo \& NO GUEIRA, Adriano. Subjetividade, Conhecimento e Ambiente. In.: NO GUEIRA, Adriano. Ambiência: direcionando a visão do educador para o III milênio. Taubaté, SP: Cabral Editora Universitária, 2000. 176 p. p. 11-18.

FREITAG, Bárbara. Prefácio IN.: MOREL, Regina Lúcia de Moraes. Ciência e Estado - A Política Científica no Brasil. São Paulo: Ed. T. A. Q ueiroz Ltda., 1979. p. 15-26.

GEERTZ, Clifford. A Interpretação das Culturas. Rio de janeiro: LTC, 1989.

HABERMAS, Jürgen. Conhecimento e Interesse. In. BENJAMIN, Walter; HO RKHEIM ER, M ax; ADO RN O, Theodor W. \& HABERMAS, Jürgen. Os pensadores - Textos escolhidos. São Paulo: Abril Cultural, 1980. 343 p. p. 301-312.

. Ciencia y técnica como ideologia. Madrid, ES: Editorial Tecnos, 1992.

HOCHMAN, Gilberto. A Ciência entre a comunidade e o mercado: Leituras de Kuhn, Bourdieu, Knorr-Cetina e Latour. In.: PO RTO CARRERO, Vera (O rg.). Filosofia, História e Sociologia das Ciências. Rio de Janeiro: Fiocruz, 1994. 268 p. p. $199-232$. 
KU HN , Thomas S. A Estrutura das Revoluções Científicas. São Paulo: Perspectiva, 2003.

LIM A, N ísia Trindade. Valores sociais e atividade científica: Um retorno à agenda de Robert Merton. In.: PORTOCARRERO, Vera (O rg.). Filosofia, História e Sociologia das Ciências. Rio de Janeiro: Fiocruz, 1994. 268 p. p. 151-173.

LIMA, Hermano Machado F. Ciência e complexidade. In.: CASTRO, Gustavo de; CARVALHO , Edgard de Assis \& ALM EIDA, M aria da Conceição de (O rgs.). Ensaios de Complexidade. Porto Alegre: Sulina, 2002. 245 p. p. 49-54.

LUHMANN, Niklas. Sociedad y sistema: la ambición de la teoría de los sistemas. [trad. Santiago López Petit y Dorthee Schmitz. Introd. Ignácio Izuzquiza]. Barcelona: Paidós, 1997.

LU H M AN N, Niklas. Porque uma teoria dos sistemas? In: NEVES, Clarissa E. B. \& SAMIOS, Eva M. Niklas Luhmann - a nova teoria dos sistemas. Porto Alegre: Editora da Universidade/Goethe-Institut, 1997ª.

MANNHEIM, Karl. 0 Homem e a Sociedade. Rio de Janeiro: Zahar, 1962.

. Ideologia e Utopia. Rio de Janeiro: Zahar, 1972.

. A natureza do conhecimento político. In.: FO RACHI, Marialice M. (O rg.). Mannheim: Sociologia. São Paulo: Àtica, 1982. 215 p. p. 166-187.

MARX, k. \& ENGELS, F. A ideologia alemã. São Paulo: Hucitec, 1993.

MATURANA, Humberto \& NOGUEIRA, Adriano. Cuestines sobre el acto de conocimiento, In.: NOGUEIRA, Adriano. Ambiência - Direcionando a visão do educador para o III milênio. Taubaté, SP: Cabral Editora Universitária, 2000. 176 p. p. 19-27.

M ELLO, Thiago de. Para os que virão. Disponível em < http://www.fisica.ufpb.br/ $\sim$ romero/port/qa tm.htm> acesso em: 13 dez. 2005.

MILLS, C. Wright. A imaginação sociológica. Rio de Janeiro: Zahar, 1975.

MOREL, Regina. Ciência e Estado - a política científica e tecnológica no Brasil. Queiroz, LTDA, 1979.

M O RIN, Edgar. A cabeça bem feita - repensar a reforma, reformar o pensamento. 
Rio de Janeiro: Bertrand Brasil, 2000a

. Ciência com consciência. Rio de Janeiro: Bertrand Brasil, 2000b.

Educar na era planetária: o pensamento complexo como método de aprendizagem no erro e na incerteza humana. São Paulo: Cortez; Brasília, DF: UNESCO , 2003.

NICO LESCU, Basarab. 0 Manifesto da Transdisciplinaridade. São Paulo: Triom, 1999.

NO GUEIRA, Adriano. Ambiência - Direcionando a visão do educador para o III milênio. Taubaté, SP: Cabral Editora Universitária, 2000.

NUNES, João Arriscado. Um Discurso sobre as Ciências 16 anos depois. In: SANTOS, Boaventura de Souza (O rg.). Conhecimento Prudente para uma Vida Decente - 'Um Discurso sobre as Ciências' revisitado. São Paulo: Cortez, 2004. 821 p. p. 59-83.

O 'SULLIVAN, Edmund. Aprendizagem transformadora - U ma visão educacional para o século XXI. São Paulo: Cortez: Instituto Paulo Freire, 2004.

PIAGET, Jean. Sabedoria e ilusões a filosofia. In.: Os pensadores. São Paulo: Abril Cultural, 1975.

RO UANET, Sérgio Paulo. Mal-estar na Modernidade. São Paulo: Companhia das Letras, 1993.

SANTOS, Boaventura de Souza. Um discurso sobre as ciências. Porto: Edições Afrontamento, 1987.

. Pela mão de Alice: o social e o político na pós-modernidade. São Paulo: Cortez, 1997.

- A crítica da razão indolente - Contra o desperdício da experiência. Vol 1 - Para um novo senso comum: A ciência, o direito e a política na transição paradigmática. São Paulo: Cortez. 2000.

A Universidade no século XXI_- Para uma reforma democrática e emancipatória da Universidade. São Paulo: Cortez, 2004. 
Sociologias, Porto Alegre, ano 8, no 15, jan/jun 2006, p. 88-135

0 Fórum Social Mundial: Manual de uso. São Paulo: Cortez, 2005.

TAVARES DOS SANTOS, José Vicente. Novas questões sociais mundiais, projetos sociais e culturais e a planificação emancipatória. In.: Humanas: Revista do Instituto de Filosofia e Ciências H umanas/U niversidade Federal do Rio Grande do Sul, Instituto de Filosofia e Ciências Humanas. Vol. 24, n²1/2, p. 163-185, jan/jun 2001.

W ALLERSTEIN, Immanuel. 0 fim do mundo como o concebemos: Ciência social para o século XXI. Rio de Janeiro: Revan, 2002. 2003.

Utopística: As decisões históricas do século vinte e um. Petrópolis, RJ: Vozes, 


\section{Resumo}

O objetivo deste texto é demarcar o sentido que tem assumido, no contexto do capitalismo, a relação entre sociedade e conhecimento científico. 0 desenvolvimento do capitalismo e da ciência moderna prosperaram a partir de uma relação de interdependência entre a lógica mercantil do primeiro e os pressupostos lineares da segunda. N este sentido, ao racionalismo cartesiano podem ser creditadas muitas das conseqüências indesejadas que o sistema mundo tem produzido ao longo dos dois últimos séculos. Entrementes, em face das promessas de progresso não realizadas pelo capitalismo em sua versão cognitiva, a ciência moderna, passa a ser questionada em seu mais elementar fundamento, o domínio da natureza pelo homem. De sua crítica nascem e/ou ressurgem perspectivas não-lineares, que procuram considerar novas conexões e/ou saberes entre consciência e existência, entre sujeito e objeto, entre homem e natureza, entre sociedade e conhecimento. Nossa expectativa é que este debate, marcado por antagonismose tensões, menos intransparente quanto mais impertinente, possa contribuir para um diálogo que deságüe em um conhecimento menos obtuso, porque atencioso para com a complexidade da realidade. Um novo conhecimento capaz de se reconciliar, humildemente, com a sabedoria, necessária e urgente, que irá permitir ao homem, ao fazer outras e novas escolhas, nascer de novo.

Palavras-chave: sociedade capitalista, interesse, conhecimento científico, complexidade, ecologia de saberes. 


\section{Knowledge and society: impertinent dialogues}

\section{Alexandre Virgínio}

This text is aimed at outlining the meaning that the relationship between society and scientific knowledge has taken under the context of capitalism. Capitalist development and modern science advanced from a relationship of interdependence between mercantile logic of the former and the linear assumptions of the latter. Therefore, several unwanted consequences produced by the system in the last centuries can be credited to Cartesian rationalism. In the meanwhile, in face of 
unfulfilled promises of capitalism in its cognitive version, modern science starts to be challenged in its most basic fundament: man's domination over nature. $N$ onlinear perspectives emerge or re-emerge from its criticism, which seek to consider new connections and/or knowledges between consciousness and existence, between subject and object, between man and nature, between society and knowledge. O ur expectation is that such debate, marked by antagonism and tensions, more transparent as it is more impertinent, can contribute to a dialogue that ends in knowledge that is less obtuse for attending to reality's complexity. A new knowledge able to humbly reconcile with the necessary and urgent wisdom that will allow man to make other and new choices - to be born again.

Key words: capitalist society, scientific knowledge, complexity, ecology of knowledges. 